\title{
Petrogenesis of the Early Cretaceous Hongshan Complex in the Southern Taihang Mountains: Constraints from Element Geochemistry, Zircon U-Pb Geochronology and Hf Isotopes
}

\author{
Xiaolei Chu ${ }^{1}$, Jinggui Sun ${ }^{1,2, *}$, Fanting Sun ${ }^{1,3}$, Yanxiong Mei ${ }^{4, *}$, Yang Liu ${ }^{1}$, Lanjing Men ${ }^{5}$, Keqiang Zhao ${ }^{1,6}$ \\ and Xiaotian Zhang ${ }^{1,7}$
}

Citation: Chu, X.; Sun, J.; Sun, F. Mei, Y.; Liu, Y.; Men, L.; Zhao, K.; Zhang, X. Petrogenesis of the Early Cretaceous Hongshan Complex in the Southern Taihang Mountains: Constraints from Element Geochemistry, Zircon U-Pb Geochronology and Hf Isotopes. Minerals 2021, 11, 1111. https:// doi.org/10.3390/min11101111

Academic Editors: Sung Won Kim and Seong-Jun Cho

Received: 7 September 2021

Accepted: 7 October 2021

Published: 10 October 2021

Publisher's Note: MDPI stays neutral with regard to jurisdictional claims in published maps and institutional affiliations.

Copyright: (c) 2021 by the authors. Licensee MDPI, Basel, Switzerland. This article is an open access article distributed under the terms and conditions of the Creative Commons Attribution (CC BY) license (https:/ / creativecommons.org/licenses/by/ $4.0 /)$
1 College of Earth Science, Jilin University, Changchun 130061, China; zhuxl19@mails.jlu.edu.cn (X.C.); sunft21@mails.jlu.edu.cn (F.S.); liuy18@mails.jlu.edu.cn (Y.L.); zkeqiang@mail.cgs.gov.cn (K.Z.); zxt15@mails.jlu.edu.cn (X.Z.)

2 Key Laboratory of Mineral Resources Evaluation in Northeast Asia, Ministry of Natural Resources, Changchun 130061, China

3 Institute of Bureau of Noferrous Metals Geological Prospecting of Jilin Provience, Changchun 130012, China

Institute of Mineral Resources, Chinese Academy of Geological Sciences, Beijing 100037, China

5 Changchun Institute of Technology, Changchun 130021, China; 0215053@ccit.edu.cn

6 Institute of Geophysical and Geochemical Exploration, Chinese Academy of Geological Sciences, Langfang 065000, China

7 School of Earth Science, East China University of Technology, Nanchang 330013, China

* Correspondence: sunjinggui@jlu.edu.cn (J.S.); meiyx@sohu.com (Y.M.)
Abstract: The Hongshan complex, located in the southern part of the Taihang Mountains in the central part of the North China Craton, consists of syenite stocks (including fine-grained biotite aegirine syenite, medium-grained aegirine gabbro syenite, coarse-grained aegirine gabbro syenite, syenite pegmatite, and biotite syenite porphyry), with monzo-diorite and monzo-gabbro dikes. This paper presents zircon $\mathrm{U}-\mathrm{Pb}$ ages and $\mathrm{Hf}$ isotope data and whole-rock geochemical data from the Hongshan complex. LA-ICP-MS zircon U-Pb age from the fine-grained biotite aegirine syenite, monzo-diorite, and monzo-gabbro are $129.3 \pm 2.0 \mathrm{Ma}, 124.8 \pm 1.3 \mathrm{Ma}$, and $124.1 \pm 0.9 \mathrm{Ma}$, respectively, indicating their emplacement in the Early Cretaceous when the North China Craton was extensively reactivated. The monzo-diorite and monzo-gabbro have low $\mathrm{SiO}_{2}$ contents (48.94-57.75 wt\%), total alkali contents (5.2-9.4 $\mathrm{wt} \%)$, and $\varepsilon \mathrm{Hf}(\mathrm{t})$ values of -22.3 to -18.4 and are enriched in $\mathrm{MgO}(4.0-8.2 \mathrm{wt} \%), \mathrm{Al} 2 \mathrm{O} 3$ (14.3-15.8 wt\%), light rare earth elements (LREEs) and large ion lithophile elements (LILEs). Interpretation of elemental and isotopic data suggests that the magma of monzo-diorite and monzo-gabbro were derived from partial melting of the enriched lithospheric mantle metasomatized by slab-derived hydrous fluids. Syenites with high alkali $\left(\mathrm{K}_{2} \mathrm{O}+\mathrm{Na}_{2} \mathrm{O}=9.4-13.0 \mathrm{wt} \%\right)$ and $\mathrm{Sr}$ contents (356-1737 ppm) and low $\mathrm{Yb}$ contents (0.94-2.65 ppm) are enriched in $\mathrm{Al}\left(\mathrm{Al}_{2} \mathrm{O}_{3}=16.4-19.1 \mathrm{wt} \%\right)$, but depleted in $\mathrm{MgO}(0.09-2.56 \mathrm{w} \%), \mathrm{Cr}(\mathrm{Avg}=7.16 \mathrm{ppm}), \mathrm{Co}(\operatorname{Avg}=6.85 \mathrm{ppm})$ and Ni (Avg = $9.79 \mathrm{ppm})$, showing the geochemical features of adakitic rocks associated with thickened lower crust. Combining zircon ${ }^{176} \mathrm{Hf} /{ }^{177} \mathrm{Hf}$ ratios of 0.282176 to $0.282359, \varepsilon \mathrm{Hf}(\mathrm{t})$ values of -18.3 to -11.8 and $\varepsilon \mathrm{Nd}(\mathrm{t})$ values of -11.1 to -8.2 , we conclude that the syenite magma was derived from the mixing of the thickened lower crust and the enriched lithospheric mantle magma. These magma processes were controlled by Paleo-Pacific plate subduction and resulted in the destruction and thinning of the central North China Craton.

Keywords: Hongshan complex; syenite; diorite-gabbro; crust-mantle interaction; Southern Taihang Mountains; North China Craton

\section{Introduction}

The North China Craton (NCC), one of the oldest landmasses on Earth [1], experienced stable development from the formation of the basement at $\sim 1.8 \mathrm{Ga}$ to the Triassic. In the 
Early Jurassic, the NCC was reactivated and was disturbed as the lithosphere thinned due to the subduction of the Paleo-Pacific plate. The thickness of the NCC decreased from approximately $200 \mathrm{~km}$ in the Paleozoic to $80-120 \mathrm{~km}$ in the Cenozoic [2-4]. The margins and interior of the NCC are associated with Mesozoic large-scale mantle-crust magma activities, accompanied by the uplift and extension of the continental crust [5-7]. With the recent implementation of many research programs focusing on the NCC, it has been recognized by many geologists that the NCC was destroyed on a large scale in the Mesozoic [8]. However, there are different views on the dominant mechanism and dynamic background of NCC lithospheric thinning [2,3,8-12].

The Handan area is located in the southern part of the Taihang Mountains in the central part of the NCC, which is also the westernmost boundary of NCC destruction [3]. The Mesozoic regional magmatic activity is strong $[13,14]$, which is a good place to study the lithospheric thinning mechanism in the central NCC. Traditionally, the alkaline rocks, typical rocks in the lithospheric extensional environment, are the products of the lower crust-mantle interaction during collisional orogenesis and lower crust thinning and are a shallow crust-level manifestation of and a natural "window" to magnify deep geodynamic processes [15-21]. Therefore, this paper selects the early Cretaceous Hongshan alkaline complex exposed in the southern end of the Taihang Mountains tectonomagmatic belt as the focus of this study $[22,23]$ (Figure 1a). Based on previous studies, we systematically carry out field investigations, the petrology, elemental geochemistry, zircon $\mathrm{U}-\mathrm{Pb}$ geochronology, and zircon Hf isotopic analysis of the Hongshan complex aimed at constraining the petrogenesis and related crust-mantle process during the craton destruction.

\section{Geological Setting and Petrology of the Hongshan Complex}

\subsection{Geological Setting}

The NCC is one of the major Archean cratons in eastern Eurasia [24,25] and has experienced geodynamic evolution for at least 3.8 billion years [26]. Based on lithological, geochemical, geochronological, structural, and metamorphic $\mathrm{P}-\mathrm{T}$ path studies of the basement rocks, it can be divided into Eastern and Western Blocks, separated by Central Orogenic Belt (Figure 1a) [27-31]. The study area is located in the southern part of the Taihang Mountains in the Central Orogenic Belt, sharing boundaries with the crust-level faults of Shanqian and Xibaiyu [32,33]. The regional Archean basement is mainly composed of tonalite-trondhjemite-granodiorite (TTG) gneiss and supracrustal rocks of the Archaean Zanhuang group [34], which is unconformity covered by the young sediments, including the sandstone of Changzhougou Formation in Mesoproterozoic, Cambrian to Ordovician (Paleozoic) marine carbonate rocks, Carboniferous to Permian (Paleozoic) sandstone and Mesozoic volcanic rocks (Figure 1b). The volcanic event of the late Mesozoic formed a large outcrop of intermediate-felsic stocks. It can be divided into three magmatic zones from west to east in this region (including the Shexian complex, the Wu'an complex, and the Hongshan complex) [34] (Figure 1b). The Shexian complex (including Pingshun, Dongye, and Fushan) is distributed in the west and consists of gabbro and diorite. The rocks of the Wu'an complex in the central part (including Qicun, Kuangcun, and Guzhen) are dioritic and monzonitic in composition. The dominant rocks of the Hongshan complex in the east part are syenites $[23,35,36]$. These rocks were all emplaced in Paleozoic carbonate and sandstone strata. 


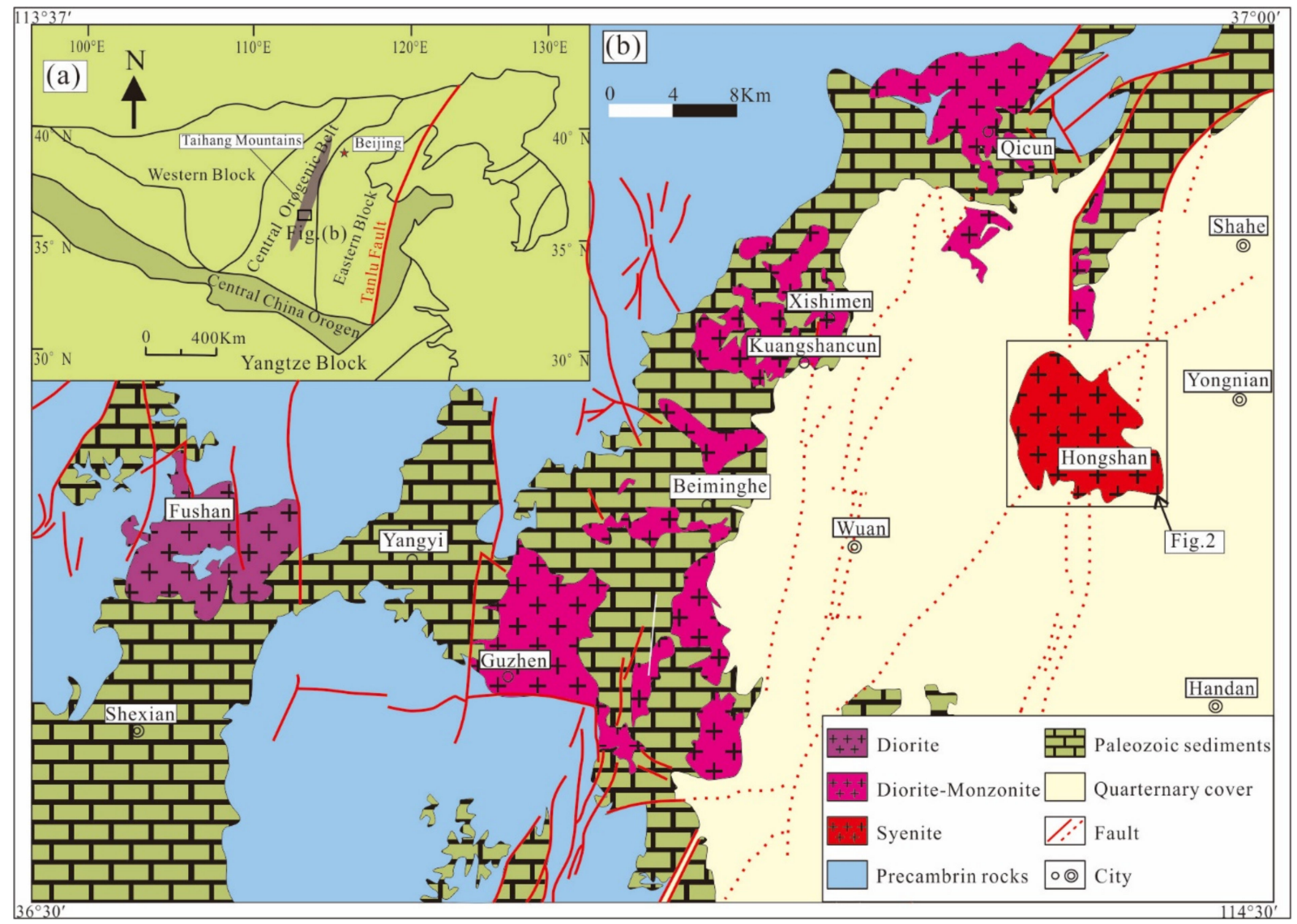

Figure 1. (a) Simplified geological map showing the major tectonic units of the North China Craton(modified after [1]); (b) Geological map showing the distribution of the intrusive complexes in Handan district (modified after [36,37]).

\subsection{Geology and Petrology of the Hongshan Complex}

The Hongshan complex is located in the easternmost part of the magmatic belt in the southern Taihang Mountains, with an exposed area of about $50 \mathrm{~km}^{2}$ (Figures $1 \mathrm{~b}$ and 2). Shen et al. (1977) divided regional intrusive rocks into gabbro diorite-hornblende diorite series, diorite-monzonite series, and alkaline syenite series, which are considered to be the products of homologous magma evolution. After that, many geologists have done much scientific research on the Hongshan complex [23,24,36-39]. Recently, based on field geological mapping and borehole logging of Hongshan complex, we have identified syenite, monzo-diorite (MD), and monzo-gabbro (GD) and divided the syenite into fine-grained biotite aegirine syenite (FBAS), medium-grained aegirine gabbro syenite (MAS), coarsegrained aegirine gabbro syenite (CAS), syenite pegmatite (SP) and biotite syenite porphyry (BSP). The geological and petrographic characteristics of each lithofacies are as follows: 


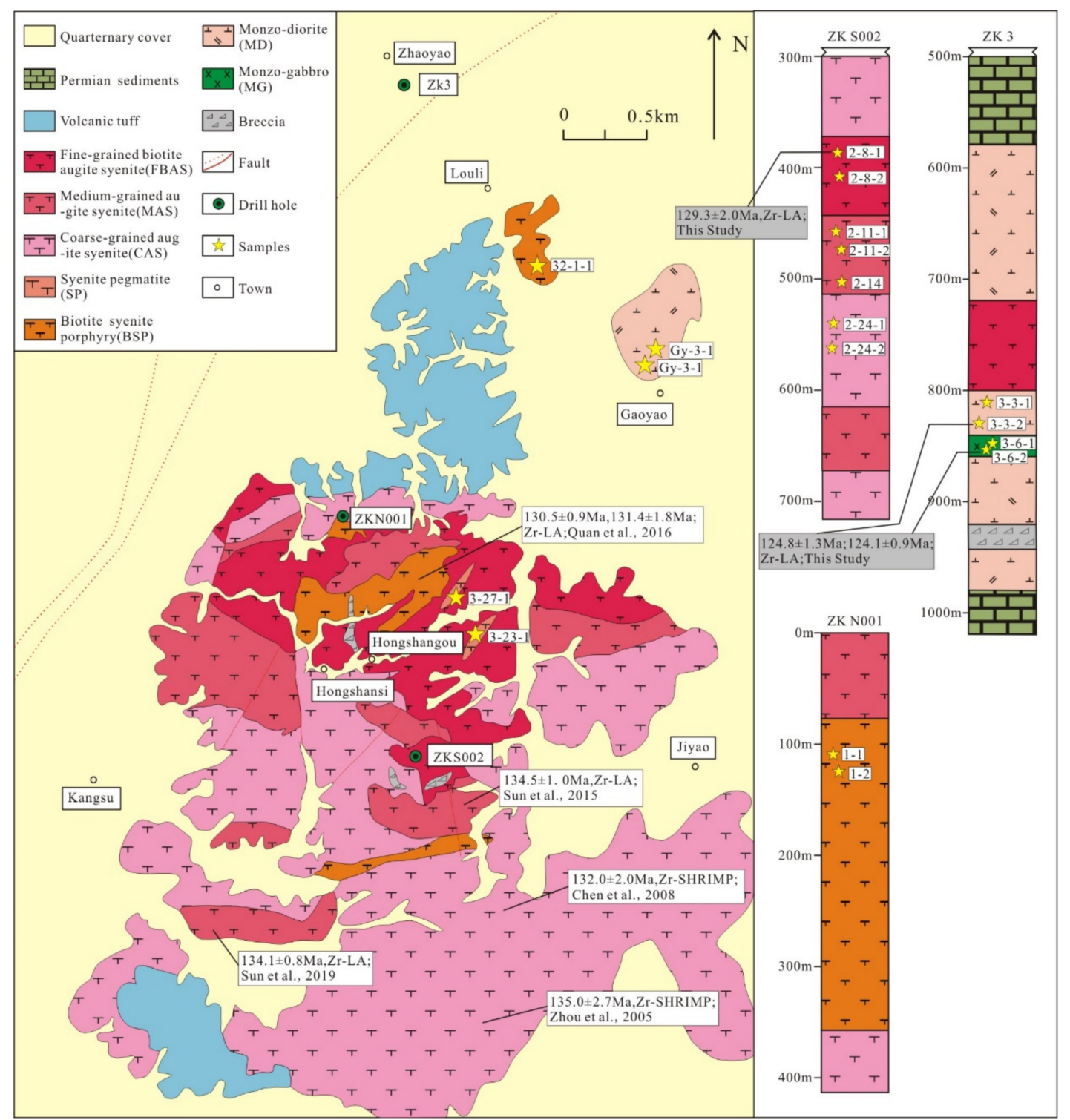

Figure 2. Geological map of the Hongshan complex and the locations of the samples(modified after No. 1 Geological Team of Hebei Bureau of Geological Exploration and Development).

\subsubsection{Syenite Facies}

(1) Fine-grained biotite aegirine syenite (FBAS)

This lithofacies occurs as an irregular intrusion with an exposed area of approximately $8 \mathrm{~km}^{2}$ (Figures 2 and 3a). The rocks are massive and fine-grained (Figure $4 \mathrm{a}$ ), and the mineral assemblage with sizes of $0.3-0.8 \mathrm{~mm}$ consists of orthoclase $(60-65 \%)$, aegirine pyroxene (13-15\%), biotite (10-15\%), plagioclase (8-12\%), with the accessory minerals of magnetite, apatite, and zircon. The majority of orthoclase crystals are either subhedral or granular. The plagioclase is subhedral with the dense polycrystalline twins and belongs to albite. Some aegirine pyroxenes are interstitial between and surrounded by the orthoclase minerals. In addition, the several aegirine pyroxenes are partially replaced by biotite minerals. Nevertheless, the primitive mineral shape of aegirine pyroxenes could be identified.

(2) Medium-grained aegirine gabbro syenite (MAS)

This lithofacies is distributed outward to the FBAS, with an approximately $6 \mathrm{~km}^{2}$ outcrop (Figure 2). The rock-forming minerals with sizes of 1-3 mm are orthoclase (75-80\%) and aegirine pyroxene (15-20\%) with the accessory minerals of the magnetite and zircon 
(Figures $3 \mathrm{~b}$ and $4 \mathrm{~b}$ ). The orthoclase is mostly plate-shaped and is overlapped by clay alteration. The aegirine pyroxene is mostly in a euhedral and subhedral columnar shape, and few are fine-grained distributed and are interstitial between and surrounded by the orthoclase minerals.

(3) Coarse-grained aegirine gabbro syenite (CAS)

The CAS phase is restricted in the margin of the Hongshan complex and covers an area of approximately $30 \mathrm{~km}^{2}$ (Figure 2). The rocks are massive and show a coarse-grained texture (Figures $3 c$ and $4 c, d$ ). The minerals (3-6 $\mathrm{mm}$ in diameters) in these rocks are composed of perthite (orthoclase and albite; $85-90 \%)$ and aegirine pyroxene (8-10\%), with accessory minerals of apatite, zircon, and magnetite. These perthite minerals show Karnofsky bicrystal and are overlapped by clay minerals. The aegirine pyroxene is a subhedral columnar in shapes and distributes in the interstice between the perthite minerals' interior.
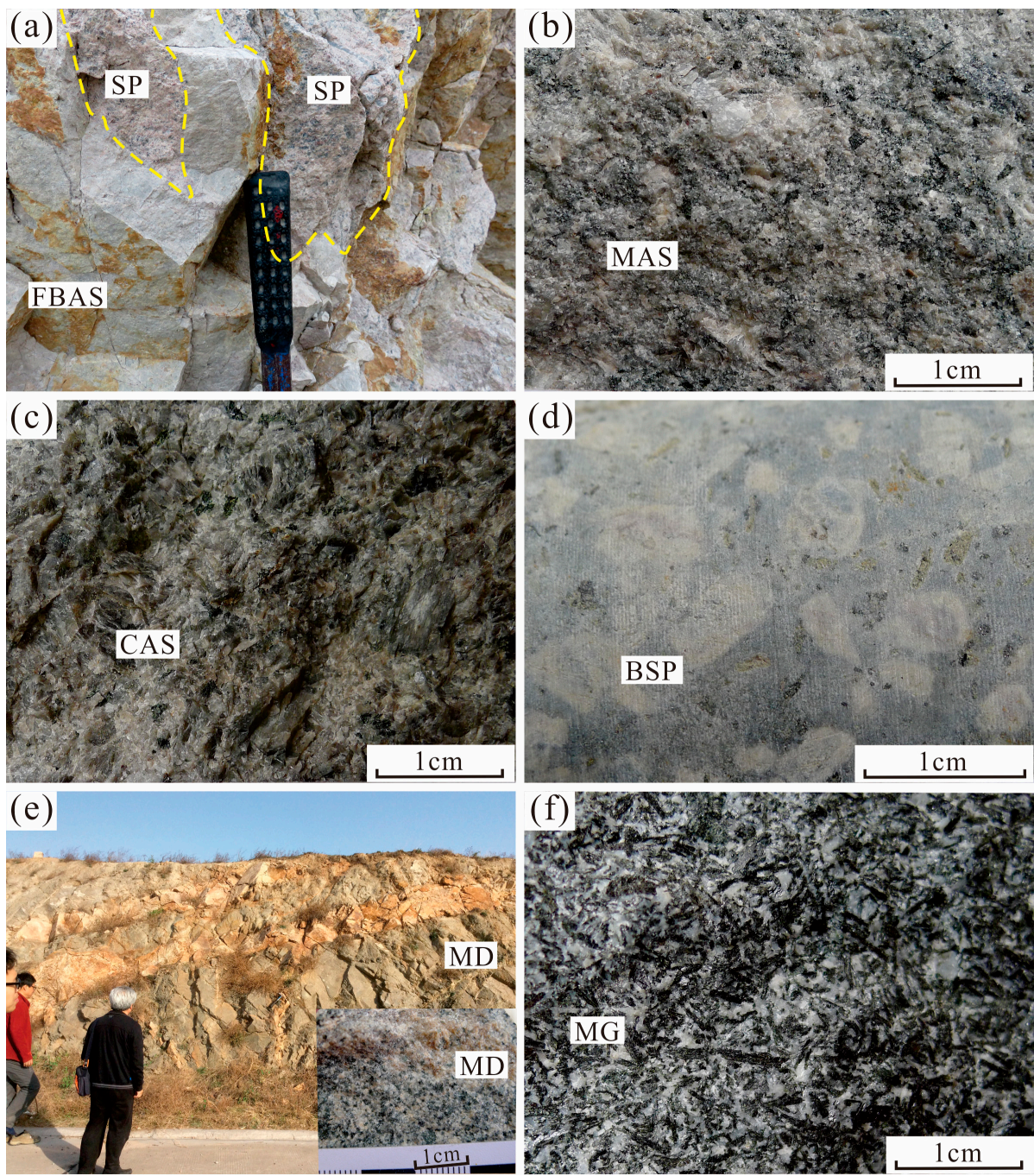

Figure 3. Characteristics of field and hand specimens of the Hongshan complex. (a) The fine-grained biotite aegirine syenite (FBAS) and syenite pegmatite (SP), showing that the fine-grained biotite aegirine syenite (FBAS) is emplaced by the syenite pegmatite (SP); (b) The medium-grained aegirine gabbro syenite (MAS); (c) The coarse-grained aegirine gabbro syenite (CAS); (d) The biotite syenite porphyry (BSP); (e) The vein fine-grained biotite hornblende monzo-diorite (MD) that intruded in syenite; (f) The fine-grained hornblende monzo-gabbro (GD).

(4) Syenite pegmatite (SP)

The lithofacies is enveloped by the FBAS stock and have a vesicle shape (Figures 2 and 3a). The rocks of this phase have massive structure and coarse-grained texture, the rock- 
forming minerals with diameters of 5-8 $\mathrm{mm}$ are orthoclase (65-70\%) and perthite (25-30\%) (Figure 4e), with the accessory minerals including apatite and zircon.
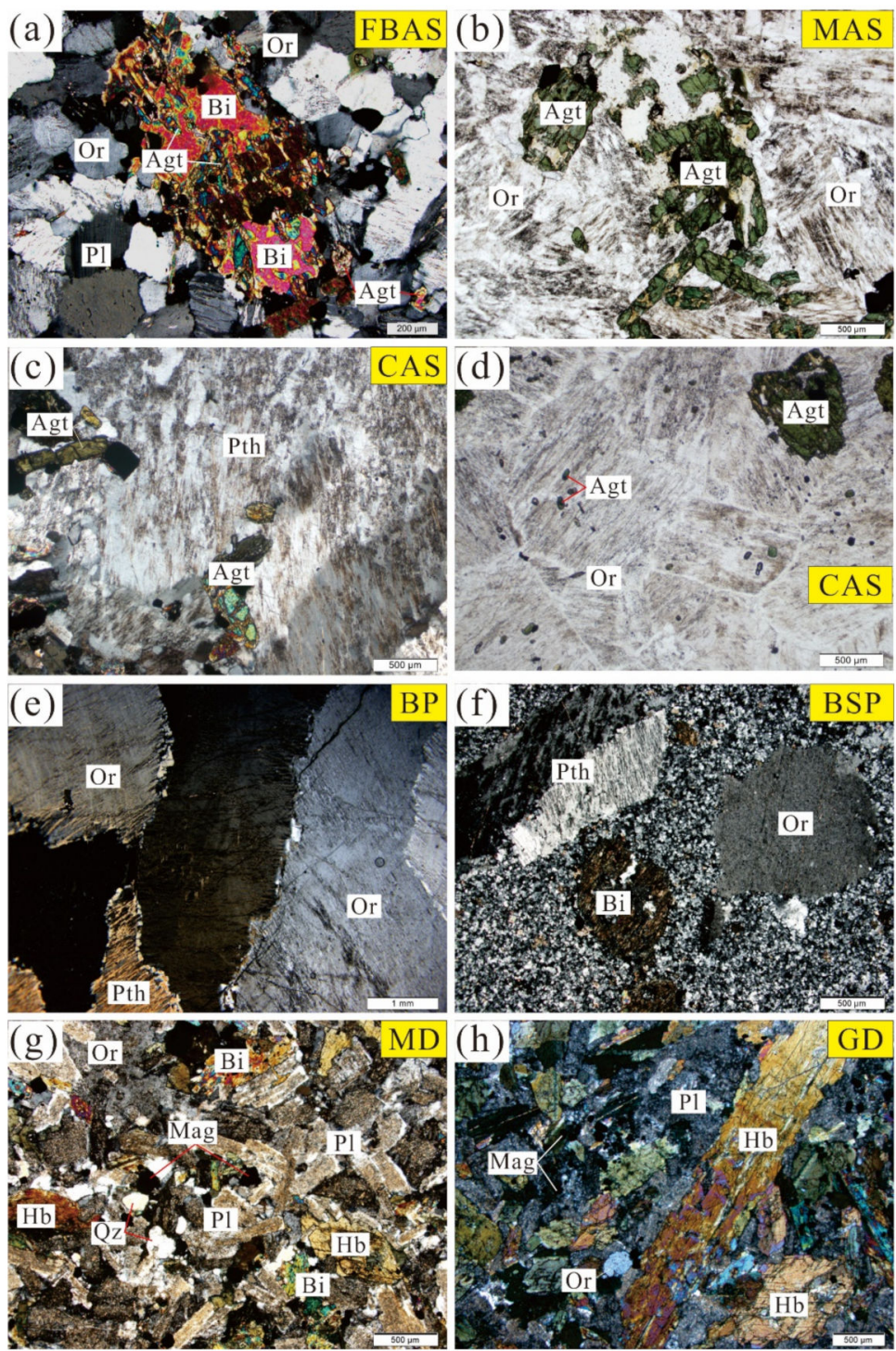

Figure 4. Photomicrographs of the Hongshan complex. (a) The FBAS, showing the residual Agt metasomatized by Bi; (b) The MAS, showing the euhedral and subhedral columnar Agt; (c,d) the CAS, showing the residual Agt and the fine-grained Agt; (e) the SP; (f) the BSP; (g) The MD; (h) the GD; Or: orthoclase, Bi: biotite, Pl: plagioclase, Agt: aegirine-augite, Pth: perthite, Hb: hornblende, Mag: magnetite. (b,d) are photographs under plane-polarized light. $(\mathbf{a}, \mathbf{c}, \mathbf{e}-\mathbf{h})$ are photographs under cross-polarized light.

(5) Biotite syenite porphyry (BSP)

The BSP rocks are shallower intrusions and have an irregular outcrop of approximately $1 \mathrm{~km}^{2}$ in the Hongshan complex (Figures 2 and 3d). They are massive and porphyritic (Figure $3 \mathrm{~d}$ ). The phenocryst minerals in these rocks are orthoclase (25-30\%), plagioclase $(15-18 \%)$, biotite $(10-12 \%)$, and the equivalent matrix $(40-45 \%)$ has a microcrystalline texture (Figure $4 \mathrm{f})$. The accessory minerals are magnetite and zircon.

\subsubsection{Fine-Grained Biotite Hornblende Monzo-Diorite (MD)}

This lithofacies is mainly distributed in the northern and deep parts of the rock mass and intrudes into syenite and strata in the form of veins. The rocks have a massive structure and euhedral subhedral fine-grained texture $(0.5-1 \mathrm{~mm}$ in diameters). These rocks are 
mainly composed of plagioclase (40-45\%), orthoclase (20-25\%), amphibole (20-25\%), biotite $(8-10 \%)$ and quartz (3-5\%). The accessory minerals are magnetite, zircon, and apatite.

\subsubsection{Fine-Grained Hornblende Monzo-Gabbro (GD)}

GD dikes are intruded into syenite and are massive and fine-grained with (0.5-1.5 mm in diameters) locally porphyritic texture (Figure $3 \mathrm{f}$ ). The mineral components are plagioclase (45-50\%), amphibole (30-35\%), orthoclase (15-20\%), and biotite (5-8\%) (Figure 4h), with accessory minerals of the magnetite and zircon. Most plagioclase and orthoclase crystals are subhedral and granular and are overlapped by the sericitization and clay alteration. The amphibole minerals have a columnar shape.

\section{Samples and Analytical Methods}

Fresh and weakly altered syenite, MD, and GD samples were collected from surface and drill core to analyze the whole rock geochemistry, single Zircon U-Pb geochronology, and in situ Hf isotope. The sample location is shown in Figure 2.

\subsection{Zircon $\mathrm{U}-\mathrm{Pb}$ Isotope Analyses}

LA-ICP-MS completed zircon U-Pb dating in the Key Laboratory of Mineral Resources Evaluation in Northeast Asia, Ministry of Land and Resources, Jilin University, Changchun, China. See [40] for the specific experimental test process. The laser ablation system is the GeoLasPro 193 nm ArF excimer laser produced by the German COMPEx company. The Agilent 7900 ICP-MS instrument is used in conjunction with the laser. Helium was used as the carrier gas of denudation material in the experiment. The instrument is optimized by using synthetic silicate glass standard reference material NIST610. In situ U-Pb analysis of zircon was carried out by the 91,500 standard zircon external correction method. The laser beam spot for sample analysis was $32 \mu \mathrm{m}$ in diameter. Isotopic ratios and age values were calculated by GLITTER and Isoplot software. The results were corrected for common lead according to the method of [41].

\subsection{Major and Trace Elements Analyses of Whole Rock}

The whole rock major and trace test of the samples in this paper was completed in the Beijing Research Institute of Uranium Geology, Beijing, China. The main elements were analyzed by X-ray fluorescence with Rigaku Rix 2100 spectrometer, and the analysis uncertainty was 1-5\%. The trace elements were analyzed by PEE lan 6000 ICP-MS, and the analysis uncertainty was $1-3 \%$. International reference materials BHVO-1, BCR-2, and AGV-1 are used as test standard samples. The detailed experimental method and test flow are shown in Reference [42].

\subsection{Zircon Lu-Hf Isotope Analyses}

In situ zircon Hf isotope ratio test was completed by LA-MC-ICP-MS in the Wuhan Sample Solution Analytical Technology Co., Ltd, Wuhan, China. The laser ablation system is Geolas HD (Coherent, Santa Clara, CA, USA), and the MC-ICP-MS is Neptune plus (SPSS v8.0, IBM Corp., Armonk, NY, USA). The signal smoothing device is also equipped in the analysis process to improve the isotope ratio test's signal stability and precision [43]. Helium is used as the carrier gas, and a small amount of nitrogen is introduced after the denudation tank to improve the sensitivity of the Hf element [44]. The experiment was carried out in single-point denudation mode. The laser diameter is $44 \mu \mathrm{m}$. Refer to [44] for detailed instrument operating conditions and analysis methods.

\section{Results}

\subsection{Zircon $\mathrm{U}-\mathrm{Pb}$ Dating}

The zircon $\mathrm{U}-\mathrm{Pb}$ data in this study are provided in Table 1, and the representative zircon cathodoluminescence (CL) images and concordia diagrams are shown in Figures 5 and 6. 
Table 1. LA-ICP-MS U-Pb zircon data for the Hongshan complex.

\begin{tabular}{|c|c|c|c|c|c|c|c|c|c|c|c|c|c|c|c|c|}
\hline & \multicolumn{3}{|c|}{ Content (ppm) } & \multirow{2}{*}{$\mathrm{Th} / \mathrm{U}$} & \multicolumn{6}{|c|}{ Isotopic Ratios } & \multicolumn{6}{|c|}{ Isotopic Ages (Ma) } \\
\hline & $\mathrm{Pb}$ & Th & $\mathbf{U}$ & & $207 \mathrm{~Pb} / 206 \mathrm{~Pb}$ & $\pm 1 \mathrm{~s}$ & $207 \mathrm{~Pb} / 235 \mathrm{U}$ & $\pm 1 \mathrm{~s}$ & $206 \mathrm{~Pb} / 238 \mathrm{U}$ & $\pm 1 \mathrm{~s}$ & $207 \mathrm{~Pb} / 206 \mathrm{~Pb}$ & $\pm \mathbf{1 s}$ & $207 \mathrm{~Pb} / 235 \mathrm{U}$ & $\pm 1 \mathrm{~s}$ & $206 \mathrm{~Pb} / 238 \mathrm{U}$ & $\pm 1 \mathrm{~s}$ \\
\hline \multicolumn{17}{|c|}{ ZKS002-8-FBAS } \\
\hline ZKS002-8-1 & 23 & 283 & 1034 & 0.27 & 0.04869 & 0.00128 & 0.13208 & 0.00366 & 0.01969 & 0.00044 & 133 & 30 & 126 & 3 & 126 & 3 \\
\hline ZKS002-8-2 & 50 & 1070 & 1726 & 0.62 & 0.04891 & 0.00113 & 0.15944 & 0.00397 & 0.02366 & 0.00053 & 144 & 26 & 150 & 3 & 151 & 3 \\
\hline ZKS002-8-3 & 10 & 254 & 394 & 0.64 & 0.05036 & 0.00175 & 0.13729 & 0.00488 & 0.01979 & 0.00045 & 212 & 43 & 131 & 4 & 126 & 3 \\
\hline ZKS002-8-4 & 14 & 122 & 246 & 0.50 & 0.05268 & 0.00161 & 0.34602 & 0.01091 & 0.04767 & 0.00108 & 315 & 35 & 302 & 8 & 300 & 7 \\
\hline ZKS002-8-5 & 14 & 455 & 518 & 0.88 & 0.05307 & 0.00160 & 0.14435 & 0.00452 & 0.01974 & 0.00045 & 332 & 34 & 137 & 4 & 126 & 3 \\
\hline ZKS002-8-6 & 108 & 722 & 1631 & 0.44 & 0.05408 & 0.00114 & 0.41988 & 0.00972 & 0.05635 & 0.00125 & 374 & 23 & 356 & 7 & 353 & 8 \\
\hline ZKS002-8-7 & 95 & 370 & 647 & 0.57 & 0.06328 & 0.00137 & 1.06136 & 0.02507 & 0.12172 & 0.00272 & 718 & 22 & 734 & 12 & 740 & 16 \\
\hline ZKS002-8-8 & 22 & 1161 & 677 & 1.72 & 0.05032 & 0.00144 & 0.13658 & 0.00409 & 0.01970 & 0.00045 & 210 & 32 & 130 & 4 & 126 & 3 \\
\hline ZKS002-8-9 & 13 & 405 & 477 & 0.85 & 0.05017 & 0.00159 & 0.13978 & 0.00458 & 0.02022 & 0.00046 & 203 & 38 & 133 & 4 & 129 & 3 \\
\hline ZKS002-8-10 & 144 & 156 & 231 & 0.67 & 0.16825 & 0.00342 & 10.73467 & 0.24206 & 0.46296 & 0.01035 & 2540 & 17 & 2500 & 21 & 2453 & 46 \\
\hline ZKS002-8-11 & 44 & 1735 & 1392 & 1.25 & 0.04863 & 0.00131 & 0.14242 & 0.00404 & 0.02125 & 0.00048 & 130 & 31 & 135 & 4 & 136 & 3 \\
\hline ZKS002-8-12 & 52 & 74 & 134 & 0.55 & 0.11000 & 0.00234 & 4.67566 & 0.10937 & 0.30842 & 0.00693 & 1799 & 19 & 1763 & 20 & 1733 & 34 \\
\hline ZKS002-8-13 & 13 & 422 & 479 & 0.88 & 0.04605 & 0.00240 & 0.12603 & 0.00589 & 0.01985 & 0.00046 & & 113 & 121 & 5 & 127 & 3 \\
\hline ZKS002-8-14 & 48 & 2927 & 1393 & 2.10 & 0.04852 & 0.00119 & 0.13556 & 0.00358 & 0.02027 & 0.00046 & 125 & 28 & 129 & 3 & 129 & 3 \\
\hline ZKS002-8-15 & 14 & 480 & 562 & 0.85 & 0.04678 & 0.00326 & 0.12572 & 0.00823 & 0.01949 & 0.00046 & 38 & 154 & 120 & 7 & 124 & 3 \\
\hline ZKS002-8-16 & 15 & 439 & 617 & 0.71 & 0.04980 & 0.00149 & 0.13674 & 0.00427 & 0.01992 & 0.00046 & 186 & 35 & 130 & 4 & 127 & 3 \\
\hline ZKS002-8-17 & 5 & 172 & 187 & 0.92 & 0.05307 & 0.00370 & 0.14393 & 0.00994 & 0.01968 & 0.00052 & 332 & 109 & 137 & 9 & 126 & 3 \\
\hline ZKS002-8-18 & 28 & 800 & 993 & 0.81 & 0.04905 & 0.00159 & 0.14322 & 0.00481 & 0.02118 & 0.00049 & 150 & 39 & 136 & 4 & 135 & 3 \\
\hline ZKS002-8-20 & 20 & 569 & 769 & 0.74 & 0.04871 & 0.00142 & 0.13937 & 0.00428 & 0.02076 & 0.00048 & 134 & 34 & 132 & 4 & 132 & 3 \\
\hline ZKS002-8-21 & 21 & 650 & 791 & 0.82 & 0.04963 & 0.00141 & 0.14255 & 0.00427 & 0.02084 & 0.00048 & 178 & 33 & 135 & 4 & 133 & 3 \\
\hline ZKS002-8-22 & 15 & 362 & 577 & 0.63 & 0.04888 & 0.00184 & 0.14473 & 0.00558 & 0.02148 & 0.00051 & 142 & 48 & 137 & 5 & 137 & 3 \\
\hline ZKS002-8-23 & 38 & 1614 & 1338 & 1.21 & 0.04605 & 0.00338 & 0.12897 & 0.00895 & 0.02031 & 0.00049 & & 163 & 123 & 8 & 130 & 3 \\
\hline \multicolumn{17}{|c|}{ ZK3-3-MD } \\
\hline ZK3-3-1 & 8 & 433 & 253 & 1.71 & 0.05000 & 0.00336 & 0.14105 & 0.00936 & 0.02048 & 0.00052 & 195 & 105 & 134 & 8 & 131 & 3 \\
\hline ZK3-3-3 & 6 & 236 & 199 & 1.19 & 0.04681 & 0.00370 & 0.12408 & 0.00970 & 0.01924 & 0.00050 & 40 & 122 & 119 & 9 & 123 & 3 \\
\hline ZK3-3-4 & 11 & 685 & 328 & 2.09 & 0.04579 & 0.00267 & 0.12582 & 0.00726 & 0.01995 & 0.00048 & 13 & 79 & 120 & 7 & 127 & 3 \\
\hline ZK3-3-5 & 5 & 219 & 165 & 1.33 & 0.04669 & 0.00330 & 0.13142 & 0.00921 & 0.02044 & 0.00050 & 33 & 107 & 125 & 8 & 130 & 3 \\
\hline ZK3-3-6 & 9 & 503 & 307 & 1.64 & 0.05072 & 0.00258 & 0.13598 & 0.00686 & 0.01947 & 0.00046 & 228 & 73 & 129 & 6 & 124 & 3 \\
\hline ZK3-3-7 & 9 & 383 & 227 & 1.69 & 0.05610 & 0.00767 & 0.14943 & 0.02000 & 0.01932 & 0.00055 & 456 & 308 & 141 & 18 & 123 & 3 \\
\hline ZK3-3-8 & 7 & 372 & 227 & 1.64 & 0.04722 & 0.00233 & 0.12444 & 0.00611 & 0.01913 & 0.00044 & 60 & 67 & 119 & 6 & 122 & 3 \\
\hline ZK3-3-9 & 5 & 256 & 177 & 1.44 & 0.05053 & 0.00351 & 0.13379 & 0.00919 & 0.01923 & 0.00049 & 219 & 110 & 127 & 8 & 123 & 3 \\
\hline ZK3-3-10 & 9 & 621 & 297 & 2.09 & 0.05051 & 0.00235 & 0.13280 & 0.00615 & 0.01909 & 0.00044 & 219 & 65 & 127 & 6 & 122 & 3 \\
\hline ZK3-3-11 & 9 & 546 & 278 & 1.96 & 0.05070 & 0.00228 & 0.13125 & 0.00589 & 0.01880 & 0.00043 & 227 & 62 & 125 & 5 & 120 & 3 \\
\hline ZK3-3-12 & 4 & 170 & 124 & 1.37 & 0.04436 & 0.00429 & 0.11917 & 0.01141 & 0.01950 & 0.00052 & 52 & 159 & 114 & 10 & 124 & 3 \\
\hline ZK3-3-13 & 9 & 490 & 281 & 1.74 & 0.05121 & 0.00242 & 0.14353 & 0.00678 & 0.02034 & 0.00047 & 250 & 67 & 136 & 6 & 130 & 3 \\
\hline ZK3-3-14 & 7 & 312 & 240 & 1.30 & 0.04870 & 0.00237 & 0.13068 & 0.00636 & 0.01948 & 0.00046 & 133 & 70 & 125 & 6 & 124 & 3 \\
\hline ZK3-3-15 & 9 & 512 & 274 & 1.87 & 0.05516 & 0.00243 & 0.14815 & 0.00653 & 0.01949 & 0.00045 & 419 & 58 & 140 & 6 & 124 & 3 \\
\hline ZK3-3-16 & 7 & 357 & 228 & 1.57 & 0.05886 & 0.00308 & 0.15946 & 0.00830 & 0.01966 & 0.00047 & 562 & 72 & 150 & 7 & 126 & 3 \\
\hline
\end{tabular}


Table 1. Cont.

\begin{tabular}{|c|c|c|c|c|c|c|c|c|c|c|c|c|c|c|c|c|}
\hline & \multicolumn{3}{|c|}{ Content (ppm) } & \multirow{2}{*}{$\mathrm{Th} / \mathrm{U}$} & \multicolumn{6}{|c|}{ Isotopic Ratios } & \multicolumn{6}{|c|}{ Isotopic Ages (Ma) } \\
\hline & $\mathrm{Pb}$ & Th & $\mathbf{U}$ & & $207 \mathrm{~Pb} / 206 \mathrm{~Pb}$ & $\pm 1 \mathrm{~s}$ & $207 \mathrm{~Pb} / 235 \mathrm{U}$ & $\pm 1 \mathrm{~s}$ & $206 \mathrm{~Pb} / 238 \mathrm{U}$ & $\pm 1 \mathrm{~s}$ & $207 \mathrm{~Pb} / 206 \mathrm{~Pb}$ & $\pm 1 \mathrm{~s}$ & $207 \mathrm{~Pb} / 235 \mathrm{U}$ & $\pm 1 \mathrm{~s}$ & $206 \mathrm{~Pb} / 238 \mathrm{U}$ & $\pm 1 \mathrm{~s}$ \\
\hline ZK3-3-17 & 10 & 572 & 296 & 1.93 & 0.05319 & 0.00252 & 0.14689 & 0.00695 & 0.02004 & 0.00047 & 337 & 65 & 139 & 6 & 128 & 3 \\
\hline ZK3-3-18 & 13 & 845 & 320 & 2.64 & 0.05171 & 0.00251 & 0.14055 & 0.00682 & 0.01972 & 0.00047 & 273 & 68 & 134 & 6 & 126 & 3 \\
\hline ZK3-3-20 & 5 & 202 & 152 & 1.32 & 0.04605 & 0.00394 & 0.12373 & 0.01014 & 0.01949 & 0.00048 & & 189 & 118 & 9 & 124 & 3 \\
\hline ZK3-3-21 & 6 & 339 & 199 & 1.70 & 0.05104 & 0.00271 & 0.13302 & 0.00705 & 0.01890 & 0.00046 & 243 & 78 & 127 & 6 & 121 & 3 \\
\hline ZK3-3-22 & 7 & 400 & 239 & 1.67 & 0.05208 & 0.00261 & 0.13646 & 0.00685 & 0.01900 & 0.00045 & 289 & 72 & 130 & 6 & 121 & 3 \\
\hline \multicolumn{17}{|c|}{ ZK3-6-MG } \\
\hline ZK3-6-1 & 17 & 1044 & 532 & 1.96 & 0.05086 & 0.00128 & 0.13852 & 0.00348 & 0.01976 & 0.00024 & 234 & 36 & 132 & 3 & 126 & 2 \\
\hline ZK3-6-2 & 16 & 860 & 516 & 1.67 & 0.05256 & 0.00138 & 0.14097 & 0.00370 & 0.01946 & 0.00024 & 310 & 37 & 134 & 3 & 124 & 2 \\
\hline ZK3-6-3 & 17 & 934 & 565 & 1.65 & 0.04824 & 0.00123 & 0.13100 & 0.00335 & 0.01970 & 0.00024 & 111 & 38 & 125 & 3 & 126 & 2 \\
\hline ZK3-6-4 & 22 & 1013 & 811 & 1.25 & 0.05014 & 0.00116 & 0.13189 & 0.00308 & 0.01909 & 0.00023 & 201 & 32 & 126 & 3 & 122 & 1 \\
\hline ZK3-6-5 & 25 & 1753 & 669 & 2.62 & 0.04605 & 0.00183 & 0.12343 & 0.00468 & 0.01944 & 0.00023 & & 84 & 118 & 4 & 124 & 1 \\
\hline ZK3-6-6 & 12 & 497 & 457 & 1.09 & 0.04632 & 0.00228 & 0.12151 & 0.00578 & 0.01903 & 0.00024 & 14 & 106 & 116 & 5 & 122 & 2 \\
\hline ZK3-6-7 & 25 & 1580 & 777 & 2.03 & 0.04819 & 0.00111 & 0.12977 & 0.00300 & 0.01954 & 0.00023 & 109 & 33 & 124 & 3 & 125 & 1 \\
\hline ZK3-6-8 & 13 & 456 & 407 & 1.12 & 0.04605 & 0.00300 & 0.11807 & 0.00750 & 0.01860 & 0.00026 & & 143 & 113 & 7 & 119 & 2 \\
\hline ZK3-6-9 & 18 & 886 & 596 & 1.49 & 0.05109 & 0.00129 & 0.13747 & 0.00347 & 0.01953 & 0.00024 & 245 & 36 & 131 & 3 & 125 & 2 \\
\hline ZK3-6-10 & 5 & 165 & 182 & 0.91 & 0.05171 & 0.00250 & 0.13855 & 0.00660 & 0.01944 & 0.00028 & 273 & 83 & 132 & 6 & 124 & 2 \\
\hline ZK3-6-11 & 11 & 542 & 370 & 1.46 & 0.05024 & 0.00151 & 0.13479 & 0.00402 & 0.01947 & 0.00024 & 206 & 46 & 128 & 4 & 124 & 2 \\
\hline ZK3-6-12 & 14 & 755 & 436 & 1.73 & 0.05005 & 0.00354 & 0.13520 & 0.00939 & 0.01959 & 0.00027 & 197 & 162 & 129 & 8 & 125 & 2 \\
\hline ZK3-6-16 & 7 & 293 & 245 & 1.20 & 0.04638 & 0.00196 & 0.12967 & 0.00541 & 0.02029 & 0.00027 & 17 & 63 & 124 & 5 & 129 & 2 \\
\hline ZK3-6-17 & 17 & 1262 & 473 & 2.67 & 0.05005 & 0.00142 & 0.13474 & 0.00381 & 0.01954 & 0.00024 & 197 & 43 & 128 & 3 & 125 & 2 \\
\hline ZK3-6-18 & 19 & 1168 & 572 & 2.04 & 0.05016 & 0.00140 & 0.13713 & 0.00381 & 0.01985 & 0.00024 & 202 & 42 & 130 & 3 & 127 & 2 \\
\hline ZK3-6-19 & 21 & 1184 & 730 & 1.62 & 0.04976 & 0.00129 & 0.13365 & 0.00346 & 0.01950 & 0.00024 & 184 & 38 & 127 & 3 & 124 & 2 \\
\hline ZK3-6-21 & 5 & 214 & 184 & 1.17 & 0.04605 & 0.00221 & 0.12249 & 0.00563 & 0.01929 & 0.00027 & & 103 & 117 & 5 & 123 & 2 \\
\hline
\end{tabular}



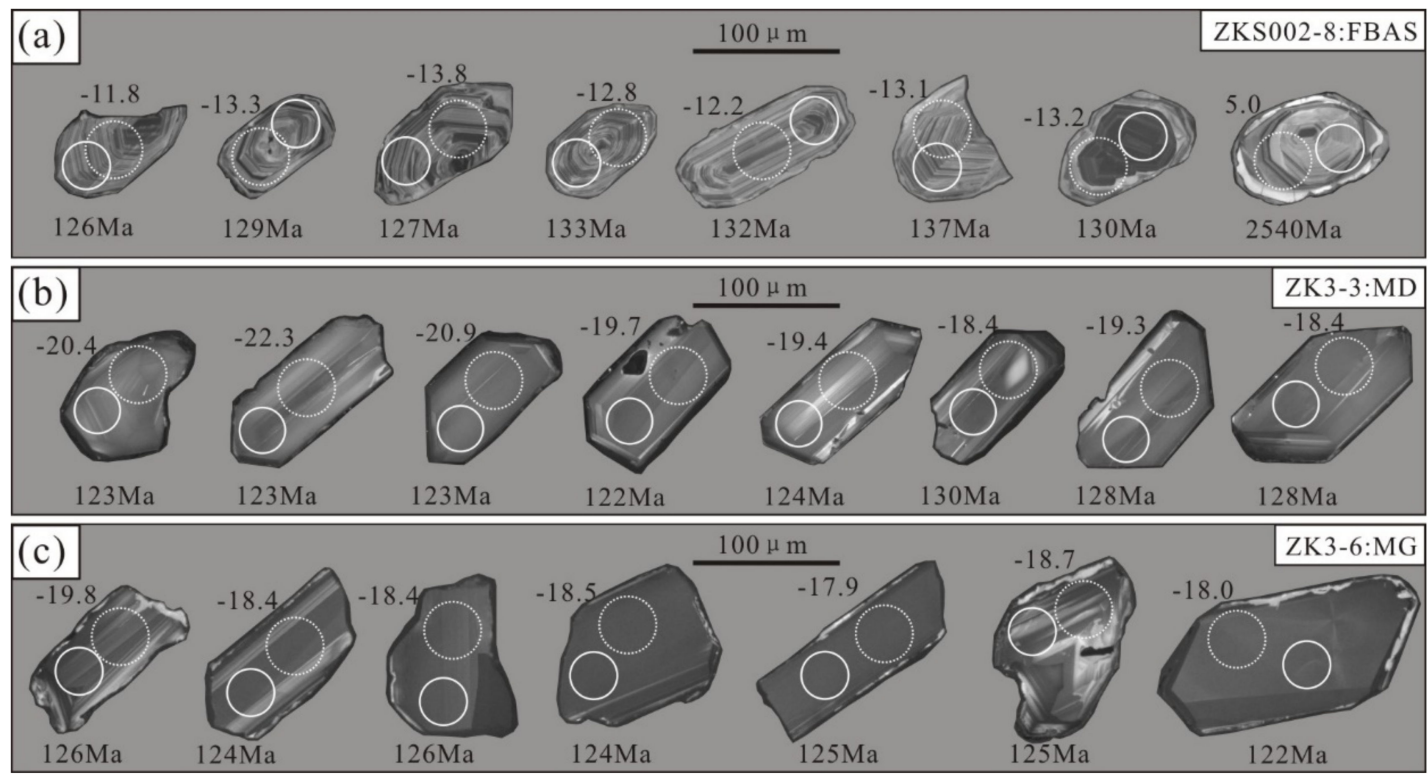

Figure 5. (a-c) Cathodoluminescence (CL) images of selected zircons from the FBAS, MD, and GD, respectively. The solid lines and the dash lines represent the locations of analysis spots used for $\mathrm{U}-\mathrm{Pb}$ dating and $\mathrm{Hf}$ isotopic analyses, respectively.

\subsubsection{FBAS (ZKS002-8)}

The zircon grains from FBAS show euhedral biconical or columnar crystals (Figure 5a). They are $100-300 \mu \mathrm{m}$ in length, $50-100 \mu \mathrm{m}$ in width, and the ratio of length to width is between 2:1 and 3:1. According to the CL image and age data of 23 zircons, two groups can be identified:

Group 1: The Th/U ratios are $0.44-0.67$. These zircons are generally round or oblate in shape, and their absorption is uneven. Some zircons have developed a white hydrothermal ring zone at the edge, indicating that they have experienced some degree of transportation and varying degrees of later hydrothermal activity. According to the concordant ages (6 grains), they formed in the Neoarchean $(2540 \pm 17 \mathrm{Ma})$, Paleoproterozoic $(1799 \pm 19 \mathrm{Ma})$, Neoproterozoic $(718 \pm 22 \mathrm{Ma})$, Carboniferous (353 $\pm 8 \mathrm{Ma}$ and $300 \pm 7 \mathrm{Ma})$, and Middle Jurassic (151 $\pm 3 \mathrm{Ma})$.

Group 2: These grains feature clear oscillatory zones in the CL images. The $\mathrm{U}$ contents are $394 \sim 1392 \mathrm{ppm}$, the Th contents are $172-2926 \mathrm{ppm}$, and the Th/U ratios are $0.27-2.10$. The ${ }^{206} \mathrm{~Pb} /{ }^{238} \mathrm{U}$ ages of 17 zircons range from 137 to $124 \mathrm{Ma}$, with a weighted average age of $129.3 \pm 2.0 \mathrm{Ma}$ (MSWD = 1.7) (Figure 6b).

\subsection{2. $\mathrm{MD}(\mathrm{ZK} 3-3)$}

The zircon grains are mostly transparent to translucent and subhedral to euhedral columnar crystals in the CL images (Figure 5b). They are 50-150 $\mu \mathrm{m}$ long and 30-80 $\mu \mathrm{m}$ wide, and the ratio of length to width is between 1:1 and 3:1. There are clear oscillatory zones in the interior. The 21 analyzed zircons contain 124-319 ppm U, 169-684 ppm Th, and $\mathrm{Th} / \mathrm{U}$ ratios of 1.16 2.64. The 21 data points are concentrated on or near the concordia line, and the weighted average ${ }^{206} \mathrm{~Pb} /{ }^{238} \mathrm{U}$ age of the zircon grains is $124.8 \pm 1.3 \mathrm{Ma}$ $($ MSWD $=1.12)$ (Figure 6d).

\subsubsection{GD (ZK3-6)}

CL images show that the zircon grains from the GD are translucent, subhedral to euhedral, and columnar. The zircons contain well-developed oscillatory zones with the internal structural characteristics of magmatic zircons. The 19 analyzed zircons contain 182-777 ppm U, 214-1753 ppm Th and Th/U ratios of 0.91-2.67. The weighted average ${ }^{206} \mathrm{~Pb} /{ }^{238} \mathrm{U}$ age of the zircon grains is $124.1 \pm 0.9 \mathrm{Ma}(\mathrm{MSWD}=1.3$ ) (Figure $6 \mathrm{f}$ ). 

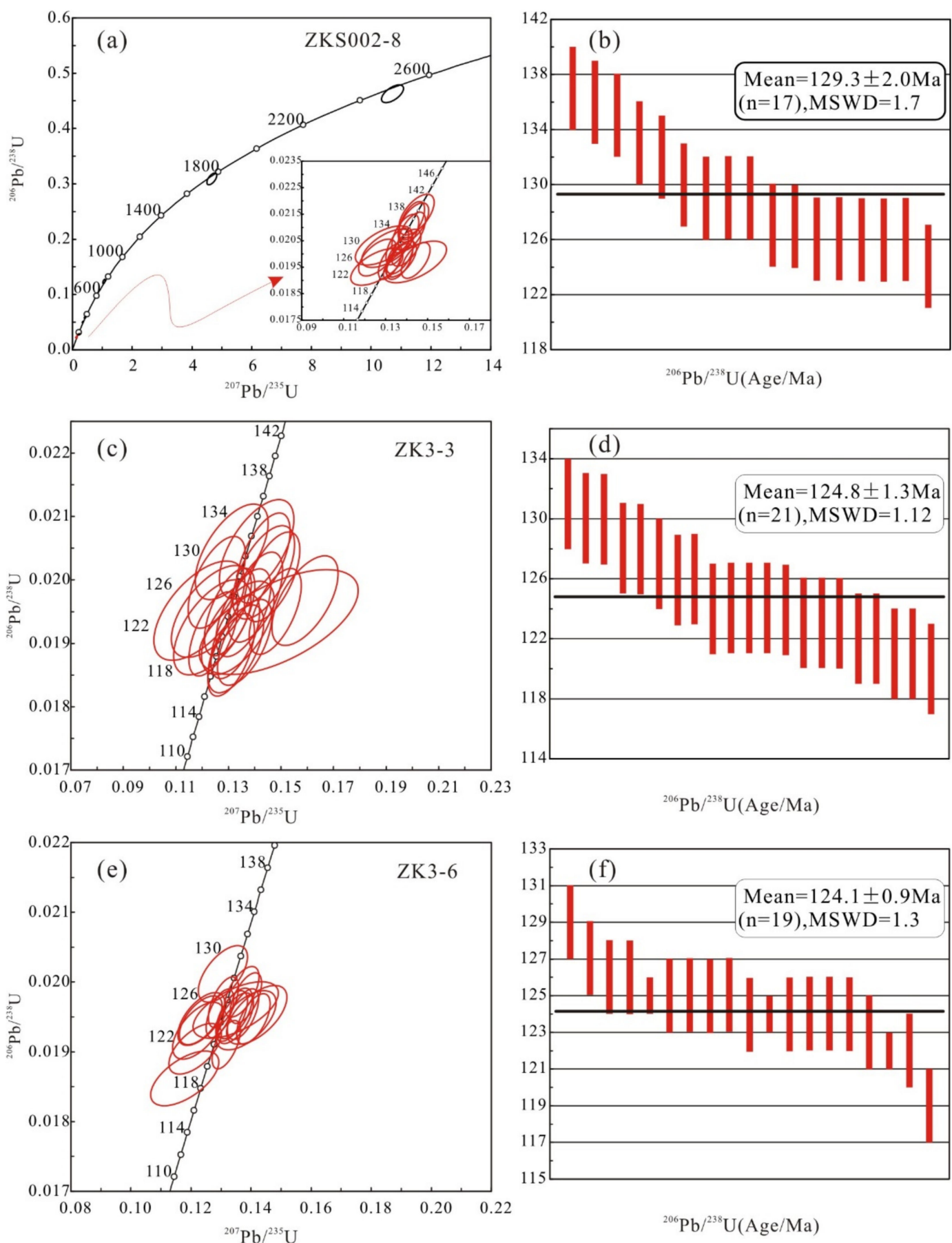

Figure 6. (a,c,e) U-Pb concordia diagrams of the FBAS, MD, and GD, respectively; (b,d,f) weighted mean ${ }^{206} \mathrm{~Pb} /{ }^{238} \mathrm{U}$ ages diagrams of the FBAS, MD, and GD, respectively. MSWD= mean square weighted deviation.

\subsection{Major Elements, Trace Elements, and REEs}

Eighteen samples, including twelve syenite samples (FBAS, MAS, CAS, SP, and BSP), four MD samples, and two GD samples from the Hongshan complex, were analyzed for geochemistry. The results are listed in Table 2. 
Table 2. Major (wt.\%) and trace (ppm) elements for the Hongshan complex.

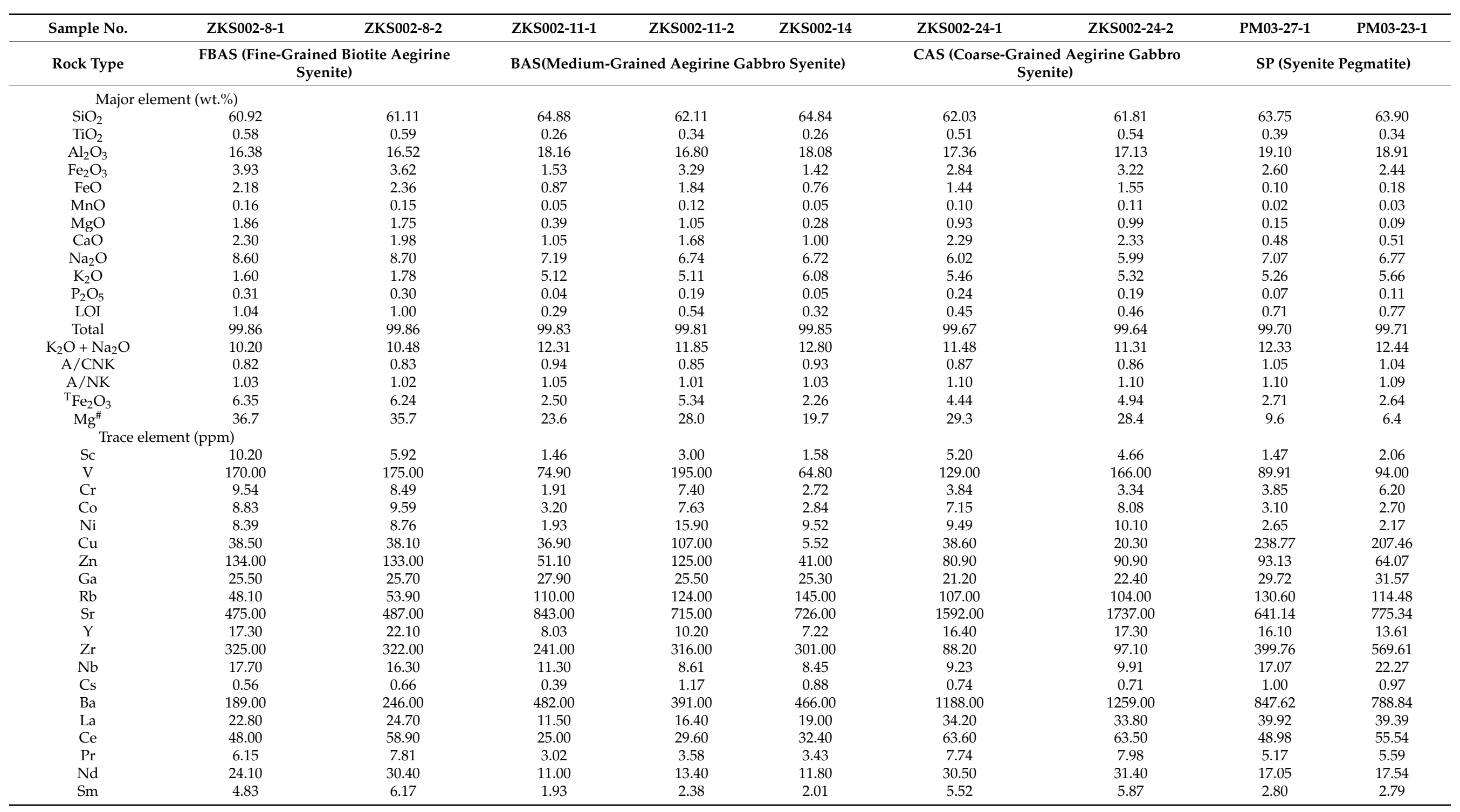


Table 2. Cont.

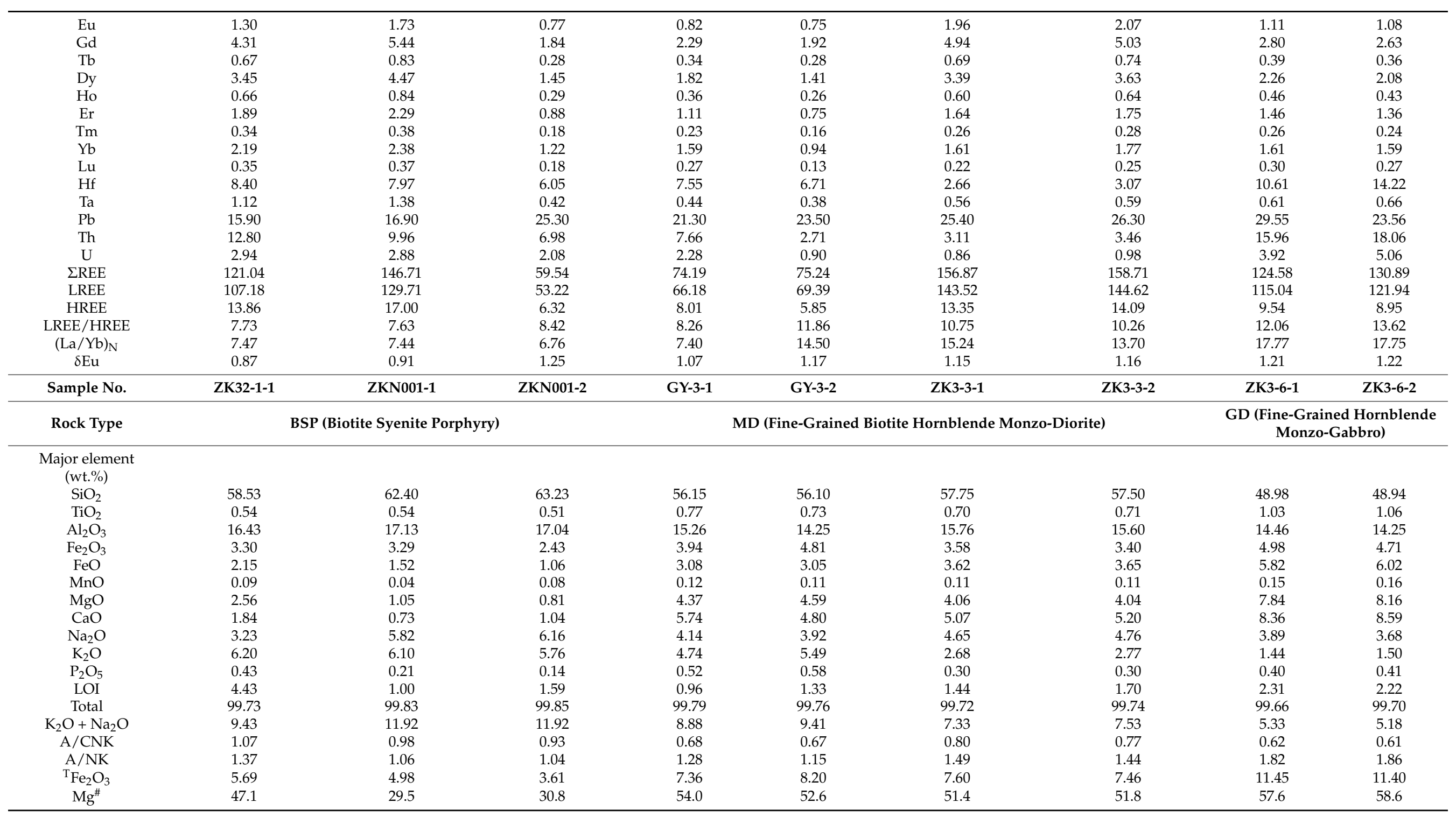


Table 2. Cont.

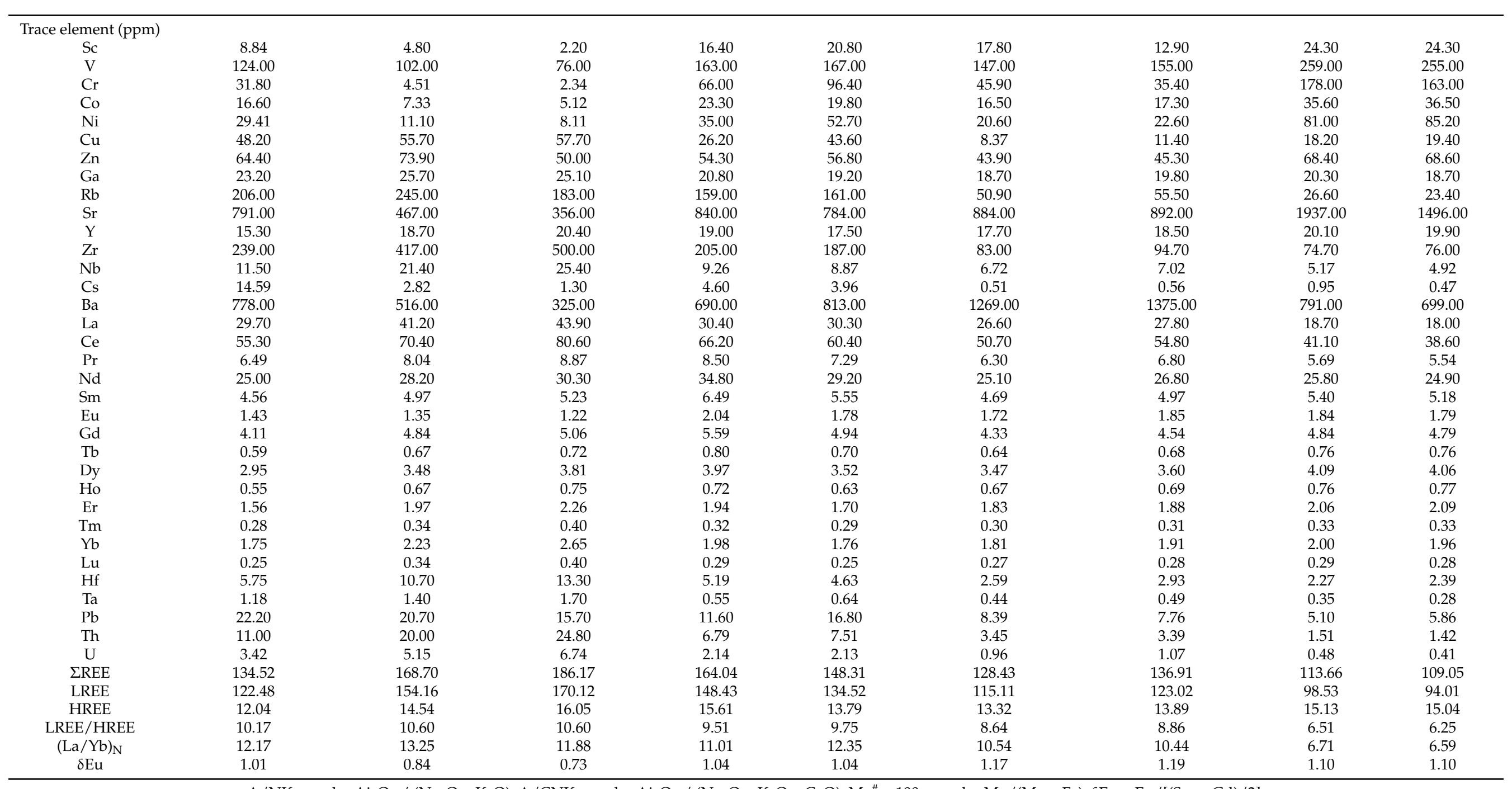

$\mathrm{A} / \mathrm{NK}=$ molar $\mathrm{Ai}_{2} \mathrm{O}_{3} /\left(\mathrm{Na}_{2} \mathrm{O}+\mathrm{K}_{2} \mathrm{O}\right) ; \mathrm{A} / \mathrm{CNK}=$ molar $\mathrm{Ai}_{2} \mathrm{O}_{3} /\left(\mathrm{Na}_{2} \mathrm{O}+\mathrm{K}_{2} \mathrm{O}+\mathrm{CaO}\right) ; \mathrm{Mg}^{\#}=100 \times$ molar Mg$/(\mathrm{Mg}+\mathrm{Fe}) ; \delta \mathrm{Eu}=\mathrm{Eu} /[(\mathrm{Sm}+\mathrm{Gd}) / 2]$. 


\subsubsection{Syenites (FBAS, MAS, CAS, SP, and BSP)}

As noted before, the syenite facies includes FBAS, MAS, CAS, SP, and BSP. The element contents of these subfacies do not vary greatly from the FBAS to the BSP. They have similar geochemical characteristics: (1) The rocks have high concentrations of $\mathrm{SiO}_{2}$ (60.92-64.88 $\mathrm{wt} \%)$ and total alkalis $\left(\mathrm{Na}_{2} \mathrm{O}+\mathrm{K}_{2} \mathrm{O}\right)(10.2-13.0 \mathrm{wt} \%)$, and they plot in the syenite field in the TAS diagram [45] (Figure 7a). In the diagram of $\mathrm{SiO}_{2}-\mathrm{AR}$, the samples fall in the alkaline area. (2) In the ANK-ACNK diagram, the component points are concentrated in the metaluminopus and peraluminous fields. (3) They are enriched in light REEs (LREEs) and large ion lithophile elements (LILEs), such as $\mathrm{Rb}$ (48.1-245 ppm), Sr (356-1737 ppm), Th (2.7-24.8 ppm), U (0.86-6.74 ppm), and K (6720-27004 ppm), and are relatively depleted in heavy REEs (HREEs) and high field strength elements (HFSEs), such as $\mathrm{Nb}$ (8.45$25.40 \mathrm{ppm}), \mathrm{Ta}(0.38-1.70 \mathrm{ppm})$ and $\mathrm{Ti}(1566-3576 \mathrm{ppm}$ ) (Figure 8a,b). (4) With magma evolution, the contents of $\mathrm{SiO}_{2}, \mathrm{Al}_{2} \mathrm{O}_{3}, \mathrm{~K}_{2} \mathrm{O}$, and $\mathrm{Nb} / \mathrm{Ta}$ and the LREEs/HREEs ratios increased, and the contents of $\mathrm{CaO}, \mathrm{Na}_{2} \mathrm{O}, \mathrm{Fe}_{2} \mathrm{O}_{3} \mathrm{t}, \mathrm{MgO}, \mathrm{TiO}_{2}$, and $\mathrm{P}_{2} \mathrm{O}_{5}$ and the $\mathrm{Sm} / \mathrm{Nd}$ ratio decreased to varying degrees (Figure 9 ).
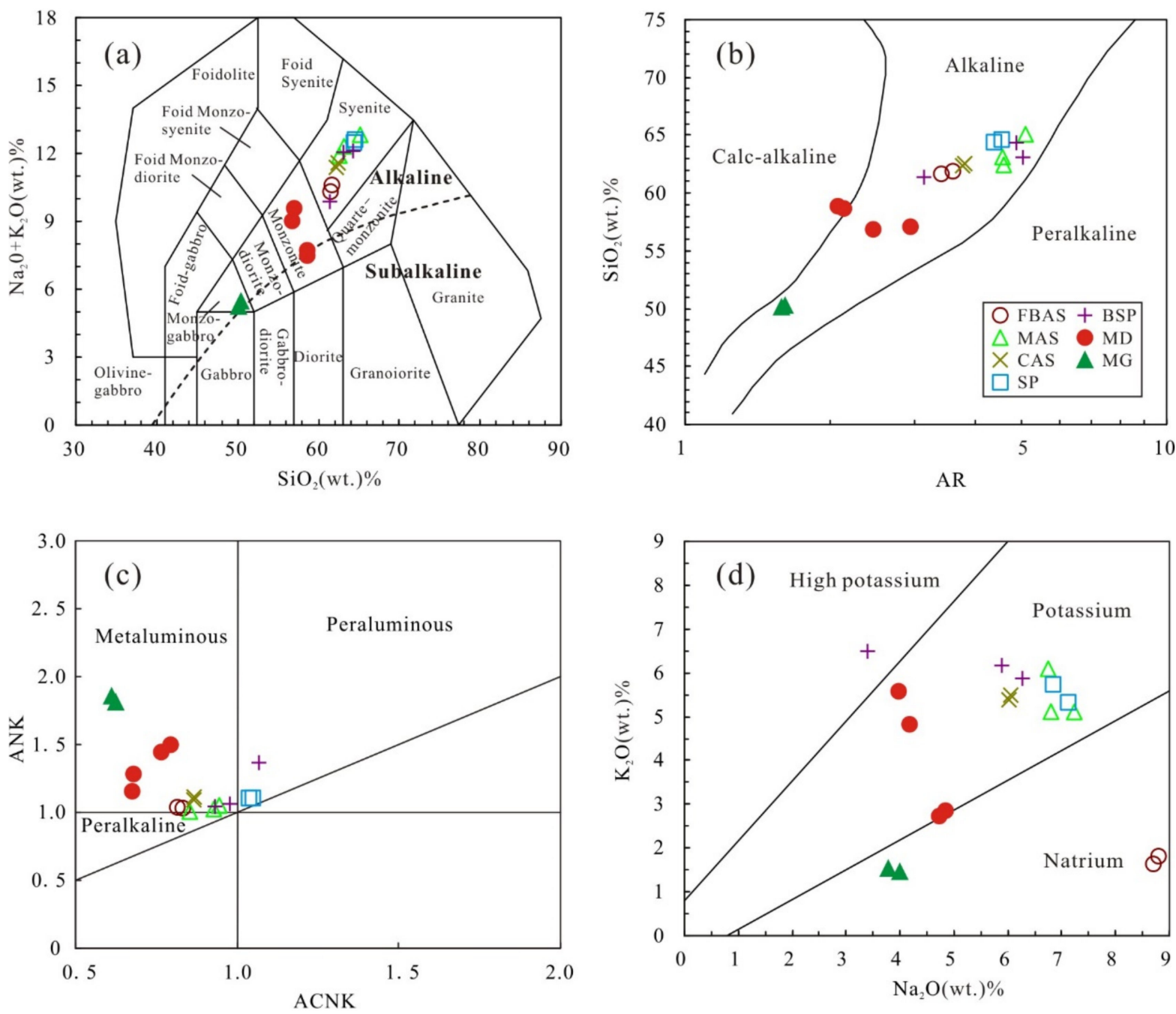

Figure 7. (a) TAS diagram for classification [45]; (b) $\mathrm{SiO}_{2}$ versus $\mathrm{AR}$ classification diagram [46], $\mathrm{AR}:\left[\mathrm{Al}_{2} \mathrm{O}{ }_{3}+\mathrm{CaO}+\left(\mathrm{Na}_{2} \mathrm{O}+\right.\right.$ $\mathrm{K} 2 \mathrm{O})] /\left[\mathrm{Al}_{2} \mathrm{O}_{3}+\mathrm{CaO}-\left(\mathrm{Na}_{2} \mathrm{O}+\mathrm{K}_{2} \mathrm{O}\right)\right]$ ( $\mathrm{wt} \%$ is the percentage calculated after the loss on ignition is removed); (c) ANK versus ACNK classification diagram [47], $\mathrm{ANK}=$ molar $\mathrm{Ai}_{2} \mathrm{O}_{3} /\left(\mathrm{Na}_{2} \mathrm{O}+\mathrm{K}_{2} \mathrm{O}\right), \mathrm{ACNK}=$ molar $\mathrm{Ai}_{2} \mathrm{O}_{3} /\left(\mathrm{Na}_{2} \mathrm{O}+\mathrm{K}_{2} \mathrm{O}+\mathrm{CaO}\right) ;(\mathbf{d}) \mathrm{K}_{2} \mathrm{O}$ versus $\mathrm{Na}_{2} \mathrm{O}$ classification diagram [48]. 

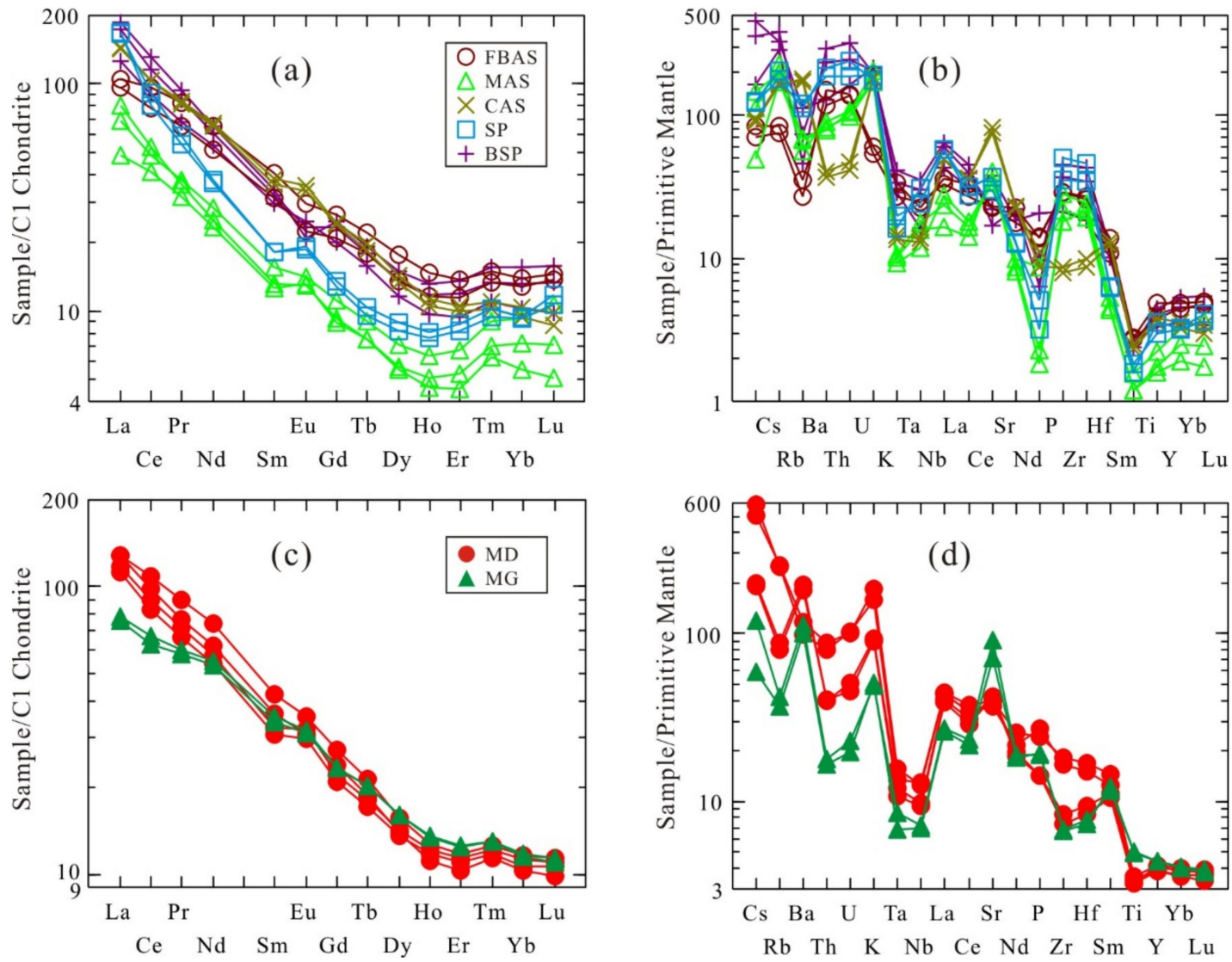

Figure 8. (a,c) Chondrite-normalized REE patterns for the Hongshan complex; (b,d) Primitive mantle-normalized trace element patterns. Chondrite and PM values are from Reference [49].

\subsubsection{Diorite and Gabbro}

(1) MD

The MD shows low concentrations of $\mathrm{SiO}_{2}(56.10-57.75 \mathrm{wt} \%$ ) and high concentrations of $\mathrm{MgO}$ (4.04-4.59 $\mathrm{wt} \%$ ), as well as relatively high magnesium numbers ranging from 51.4 to $54.0\left[\mathrm{Mg}^{\#}=\right.$ molar $\left.100 * \mathrm{MgO} /(\mathrm{MgO}+\mathrm{FeOt})\right]$. They have total alkali $\left(\mathrm{Na}_{2} \mathrm{O}+\mathrm{K}_{2} \mathrm{O}\right)$ contents of 7.33-9.41 $\mathrm{wt} \%$ and plots in the monzonite field in the TAS diagram (Figure 7a). In the $\mathrm{SiO}_{2}$-AR diagram, the samples fall in the calc-alkaline and alkaline fields (Figure $7 \mathrm{~b}$ ). In the ANK-ACNK diagram, the component points fall in the metaluminous area (Figure 7c). The MD has relatively high $\mathrm{K}_{2} \mathrm{O}$ contents and relatively low $\mathrm{P}_{2} \mathrm{O}_{5}$ contents. The MD's total REE ( $\sum$ REE) contents range from 121.04-146.71 ppm, and the REE distribution curve shows an obvious right-sloping pattern. The rocks are characterized by LREE enrichment, moderate fractionation between LREEs and HREEs $\left((\mathrm{La} / \mathrm{Yb})_{\mathrm{N}}=10.4-12.4\right)$, and slight or no negative $\mathrm{Eu}$ anomalies $(\delta \mathrm{Eu}=0.85-1.20)$. In the primitive mantle-normalized spidergram, these rocks show enrichment in LILEs, such as Rb (50.9-161 ppm), Sr (784-892 ppm), Ba (690-1375 ppm), Th (3.39-7.51 ppm), and U (0.96-2.14 ppm), and depletion in HFSEs, such as $\mathrm{Nb}$ (6.72-9.26 ppm), Ta (0.44-0.64 ppm), Zr (83-205 ppm) and Hf (2.59-5.19 ppm).

(2) GD

The GD contains $48.94 \sim 48.98 \mathrm{wt} \% \mathrm{SiO}_{2}, 11.40-11.45 \mathrm{wt} \% \mathrm{Fe}_{2} \mathrm{O}_{3} \mathrm{t}, 1.03-1.06 \mathrm{wt} \% \mathrm{TiO}_{2}$, 7.84-8.16 wt $\% \mathrm{MgO}, 1.44-1.50 \mathrm{wt}^{\circ} \mathrm{K}_{2} \mathrm{O}$, and $3.68-4.89 \mathrm{wt} \% \mathrm{Na}_{2} \mathrm{O}$ and has $\mathrm{Mg}^{\#}$ values of 57.6-58.6. These samples correspond to the monzo-gabbro basalt series in the TAS diagram (Figure 7a). The REE and trace element characteristics of the GD are similar to those of the MD. Compared with the MD, the GD has a lower fractionation degree between LREEs and HREEs $\left((\mathrm{La} / \mathrm{Yb})_{\mathrm{N}}=6.6-6.7\right)$ (Figure 8c). In the primitive mantle-normalized spidergram, these rocks show enrichment in LILEs, such as Rb (23.4-26.6 ppm), Sr (1496-1937 ppm), and 
$\mathrm{Ba}(699-791 \mathrm{ppm})$, and depletion in HFSEs, such as $\mathrm{Nb}$ (4.92-5.17 ppm), Ta (0.28-0.35 ppm), $\mathrm{Zr}$ (74.7-77.0 ppm) and Hf (2.27-2.39 ppm) (Figure 8d).
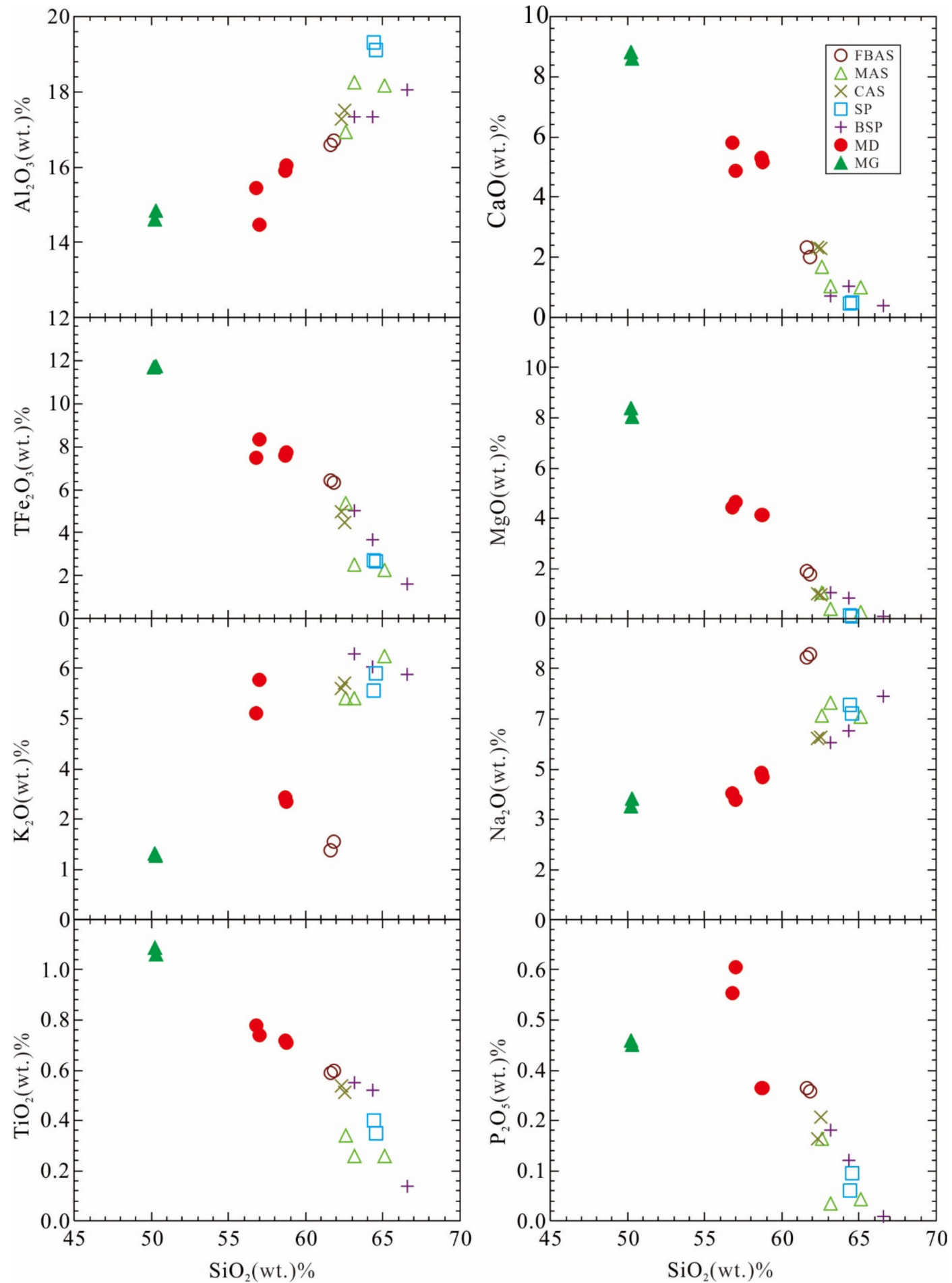

Figure 9. Harker diagrams for the Hongshan complex.

\subsection{Zircon $\mathrm{Lu}-\mathrm{Hf}$ Isotopes}

The in situ Hf isotope analysis results of zircons from the FBAS, MD, and GD from the Hongshan complex are listed in Table 3 and presented in an $\varepsilon H f(t)$ vs. age diagram in Figure 10a. 
Table 3. In situ zircon Hf isotopic compositions for the Hongshan complex.

\begin{tabular}{|c|c|c|c|c|c|c|c|c|c|c|}
\hline No. & t (Ma) & $\begin{array}{l}{ }^{176} \mathrm{Yb} \\
/^{177} \mathrm{Hf}\end{array}$ & ${ }^{176} \mathrm{Lu} /{ }^{177} \mathrm{Hf}$ & ${ }^{176} \mathrm{Hf} /{ }^{177} \mathrm{Hf}$ & 1s & $\mathbf{e}_{\mathrm{Hf}}(0)$ & $\mathbf{e}_{\mathrm{Hf}}(\mathrm{t})$ & $\mathrm{T}_{\mathrm{DM1}}(\mathrm{Hf})$ & $\mathrm{T}_{\mathrm{DM} 2}(\mathrm{Hf})$ & $f_{\mathrm{Lu} / \mathrm{Hf}}$ \\
\hline \multicolumn{11}{|c|}{ ZKS002-8-FBAS } \\
\hline ZKS002-8-3 & 126 & 0.025425 & 0.001148 & 0.282361 & 0.000020 & -14.53 & -11.80 & 1264 & 2684 & -0.97 \\
\hline ZKS002-8-5 & 126 & 0.035780 & 0.001419 & 0.282338 & 0.000010 & -15.3 & -12.64 & 1306 & 2760 & -0.96 \\
\hline ZKS002-8-8 & 126 & 0.084008 & 0.003044 & 0.282353 & 0.000010 & -14.82 & -12.25 & 1343 & 2724 & -0.91 \\
\hline ZKS002-8-9 & 129 & 0.031872 & 0.001309 & 0.282319 & 0.000009 & -16.02 & -13.31 & 1329 & 2819 & -0.96 \\
\hline ZKS002-8-10 & 2540 & 0.012299 & 0.000511 & 0.281326 & 0.000008 & -51.12 & 4.99 & 2655 & 2804 & -0.98 \\
\hline ZKS002-8-11 & 136 & 0.025782 & 0.000891 & 0.282178 & 0.000008 & -21.01 & -18.27 & 1511 & 3262 & -0.97 \\
\hline ZKS002-8-12 & 1799 & 0.003867 & 0.000135 & 0.281530 & 0.000008 & -43.92 & -4.04 & 2358 & 3091 & -1.00 \\
\hline ZKS002-8-13 & 127 & 0.028804 & 0.001222 & 0.282304 & 0.000008 & -16.55 & -13.83 & 1347 & 2866 & -0.96 \\
\hline ZKS002-8-16 & 127 & 0.038991 & 0.001456 & 0.282362 & 0.000009 & -14.49 & -11.78 & 1273 & 2683 & -0.96 \\
\hline ZKS002-8-16 & 127 & 0.014007 & 0.000542 & 0.282350 & 0.000007 & -14.9 & -12.14 & 1260 & 2715 & -0.98 \\
\hline ZKS002-8-17 & 126 & 0.024920 & 0.000937 & 0.282359 & 0.000019 & -14.60 & -11.85 & 1260 & 2689 & -0.97 \\
\hline ZKS002-8-20 & 133 & 0.031035 & 0.001327 & 0.282333 & 0.000013 & -15.5 & -12.82 & 1310 & 2775 & -0.96 \\
\hline ZKS002-8-21 & 132 & 0.029445 & 0.001248 & 0.282350 & 0.000008 & -14.91 & -12.19 & 1283 & 2719 & -0.96 \\
\hline ZKS002-8-22 & 137 & 0.019798 & 0.000915 & 0.282325 & 0.000008 & -15.81 & -13.06 & 1307 & 2797 & -0.97 \\
\hline ZKS002-8-23 & 130 & 0.034775 & 0.001211 & 0.282321 & 0.000011 & -15.95 & -13.23 & 1323 & 2812 & -0.96 \\
\hline \multicolumn{11}{|c|}{ ZK3-3-MD } \\
\hline ZK3-3-3 & 123 & 0.055182 & 0.002338 & 0.282124 & 0.000018 & -22.90 & -20.38 & 1648 & 3445 & -0.93 \\
\hline ZK3-3-5 & 130 & 0.070482 & 0.002922 & 0.282123 & 0.000022 & -22.97 & -20.49 & 1677 & 3455 & -0.91 \\
\hline ZK3-3-7 & 123 & 0.064161 & 0.002669 & 0.282070 & 0.000016 & -24.84 & -22.35 & 1743 & 3619 & -0.92 \\
\hline ZK3-3-9 & 123 & 0.082849 & 0.003469 & 0.282112 & 0.000020 & -23.33 & -20.90 & 1719 & 3490 & -0.90 \\
\hline ZK3-3-10 & 122 & 0.076025 & 0.003167 & 0.282145 & 0.000022 & -22.16 & -19.7 & 1655 & 3385 & -0.90 \\
\hline ZK3-3-12 & 124 & 0.062638 & 0.002612 & 0.282153 & 0.000025 & -21.90 & -19.40 & 1619 & 3358 & -0.92 \\
\hline ZK3-3-13 & 130 & 0.062195 & 0.002554 & 0.282180 & 0.000024 & -20.92 & -18.42 & 1577 & 3271 & -0.92 \\
\hline ZK3-3-16 & 126 & 0.091824 & 0.003736 & 0.282077 & 0.000021 & -24.57 & -22.17 & 1784 & 3602 & -0.89 \\
\hline ZK3-3-17 & 128 & 0.087753 & 0.003621 & 0.282157 & 0.000036 & -21.75 & -19.34 & 1659 & 3351 & -0.89 \\
\hline ZK3-3-19 & 128 & 0.088719 & 0.003657 & 0.282183 & 0.000042 & -20.84 & -18.43 & 1623 & 3271 & -0.89 \\
\hline \multicolumn{11}{|c|}{ ZK3-6-GD } \\
\hline ZK3-6-1 & 126 & 0.085878 & 0.003594 & 0.282145 & 0.000025 & -22.18 & -19.76 & 1676 & 3389 & -0.89 \\
\hline ZK3-6-2 & 124 & 0.102319 & 0.004309 & 0.282184 & 0.000022 & -20.80 & -18.44 & 1651 & 3271 & -0.87 \\
\hline ZK3-6-3 & 126 & 0.115486 & 0.004769 & 0.282186 & 0.000025 & -20.73 & -18.40 & 1670 & 3267 & -0.86 \\
\hline ZK3-6-5 & 124 & 0.138117 & 0.005540 & 0.282185 & 0.000024 & -20.76 & -18.50 & 1710 & 3275 & -0.83 \\
\hline ZK3-6-6 & 122 & 0.076656 & 0.003628 & 0.282196 & 0.000022 & -20.38 & -17.96 & 1602 & 3229 & -0.89 \\
\hline ZK3-6-8 & 119 & 0.049361 & 0.002223 & 0.282150 & 0.000020 & -21.99 & -19.45 & 1606 & 3363 & -0.93 \\
\hline ZK3-6-9 & 125 & 0.107329 & 0.004582 & 0.282214 & 0.000022 & -19.72 & -17.38 & 1617 & 3176 & -0.86 \\
\hline ZK3-6-12 & 125 & 0.064189 & 0.002802 & 0.282172 & 0.000021 & -21.23 & -18.75 & 1600 & 3299 & -0.92 \\
\hline ZK3-6-16 & 129 & 0.055839 & 0.002437 & 0.282186 & 0.000020 & -20.72 & -18.21 & 1563 & 3252 & -0.93 \\
\hline ZK3-6-17 & 125 & 0.131636 & 0.005386 & 0.282203 & 0.000021 & -20.13 & -17.85 & 1674 & 3218 & -0.84 \\
\hline ZK3-6-19 & 124 & 0.132792 & 0.005927 & 0.282227 & 0.000022 & -19.26 & -17.04 & 1663 & 3144 & -0.82 \\
\hline ZK3-6-21 & 123 & 0.070731 & 0.002944 & 0.282137 & 0.000018 & -22.47 & -19.99 & 1658 & 3410 & -0.91 \\
\hline
\end{tabular}
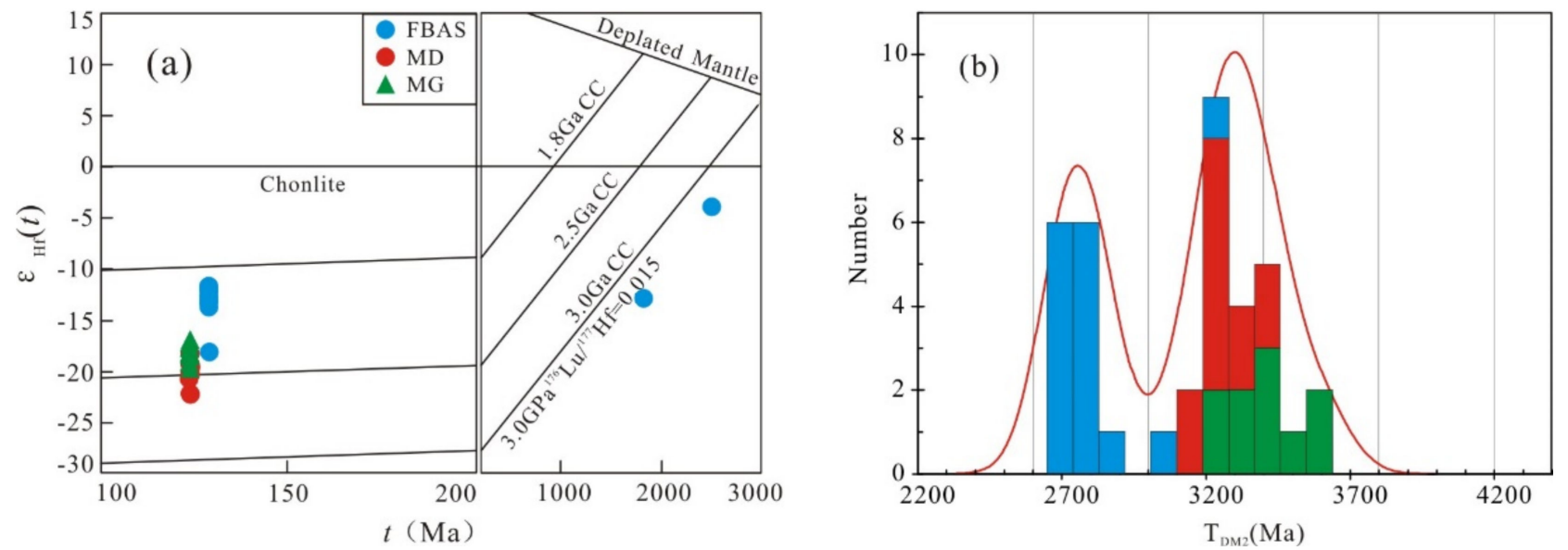

Figure 10. (a) $\varepsilon \mathrm{Hf}(\mathrm{t})$ versus crystallization age of zircons from the Hongshan complex [50]; (b) Frequency distributions of the $\mathrm{T}_{\mathrm{DM} 2}$ of zircons from the Hongshan complex. 


\subsubsection{FBAS (ZKS002-8)}

The ${ }^{176} \mathrm{Hf} /{ }^{177} \mathrm{Hf}$ values of a Neoarchean magmatic zircon grain ( $2540 \mathrm{Ma}, 1$ grain) and a Paleoproterozoic magmatic zircon grain ( 1799 Ma, 1 grain) from the FBAS are 0.281302 and 0.281525 , respectively, and their $\varepsilon \mathrm{Hf}(\mathrm{t})$ values are 5.0 and -4.0 . Their singlestage $\mathrm{Hf}$ model ages $\left(\mathrm{T}_{\mathrm{DM} 1}\right)$ are $2.66 \mathrm{Ga}$ and $2.36 \mathrm{Ga}$, and the two-stage $\mathrm{Hf}$ model ages $\left(\mathrm{T}_{\mathrm{DM} 2}\right)$ are $2.80 \mathrm{Ga}$ and $3.09 \mathrm{Ga}$, respectively. The Mesozoic magmatic zircon grains ( 129.1 Ma, 13 grains) have a ${ }^{176} \mathrm{Hf} /{ }^{177} \mathrm{Hf}$ range from 0.282176 to 0.282359 . The $\mathrm{T}_{\mathrm{DM} 1}$ values range from 1.25 to $1.51 \mathrm{Ga}(\mathrm{Avg}$. $=1.32 \mathrm{Ga})$, and the $\mathrm{T}_{\mathrm{DM} 2}$ values range from 2.68 3.26 Ga (Avg. $=2.79 \mathrm{Ga})$. The $\varepsilon \mathrm{Hf}(\mathrm{t})$ values are all negative, ranging from -18.3 to -11.8 , with a mean value of -13.0 .

\subsection{2. $\mathrm{MD}(\mathrm{ZK} 3-3)$}

The initial ${ }^{176} \mathrm{Hf} /{ }^{177} \mathrm{Hf}$ ratios of ten zircon grains from the MD vary from 0.282063 to 0.282174 . The $\varepsilon \mathrm{Hf}(\mathrm{t})$ values are all negative and range between -22.3 and -18.4 , with an average value of -20.2 . The $\mathrm{T}_{\mathrm{DM} 1}$ values range from 1.58 to $1.78 \mathrm{Ga}(\mathrm{Avg} .=1.67 \mathrm{Ga})$, and the $\mathrm{T}_{\mathrm{DM} 2}$ values range from $3.27-3.62 \mathrm{Ga}(\mathrm{Avg} .=3.42 \mathrm{Ga})$.

\subsubsection{GD (ZK3-6)}

The GD's zircon Hf isotope analysis results show that the initial ${ }^{176} \mathrm{Hf} /{ }^{177} \mathrm{Hf}$ ratios of twelve zircon grains vary from 0.282130 to 0.282214 . The $\mathrm{T}_{\mathrm{DM} 1}$ values range from 1.56 to $1.71 \mathrm{Ga}$ (mean: $1.64 \mathrm{Ga})$, and the $\mathrm{T}_{\mathrm{DM} 2}$ values range from 3.14-3.41 Ga $($ Avg. $=3.27 \mathrm{Ga})$. The $\varepsilon H f(t)$ values are concentrated between -20.0 and -17.0 (Avg. $=-18.5)$.

\section{Discussion}

\subsection{Emplacement Time and Magmatism Stage}

The southern part of the Taihang Mountains developed Mesozoic regional alkaline and calc-alkaline magmatic activities with a peak period at 124-154 Ma based on the data of the isotopic geochronology [14,39], and most volcanic events are concentrated at 127-138 Ma [51]. In the Handan area (Figure 11), we collected 20 age data sets from Pingshun rocks, Dongye rocks, Fushan rocks, Guzhen rocks, Kuangshancun rocks, and Hongshan complex. They are derived from zircon SHRIMP U-Pb ages or zircon LA U-Pb ages of syenite, monzonite, diorite, and gabbro. We can divide them into two peaks of magmatic activity: (1) 135-130 Ma monzonitic-syenite magmatism and (2) 125 Ma gabbro-diorite magmatism. In this study, the weighted mean ages of zircon grains from the FBAS are $129.3 \pm 2.0 \mathrm{Ma}$ (sample ZKS002-8). Zircon grains show typical growth zoning and euhedral grain morphology, suggesting that the ages represent the timing of emplacement of the FBAS. The MD magmatic crystallization age is $124.8 \pm 1.3 \mathrm{Ma}$, and the GD magmatic crystallization age is $124.1 \pm 0.9 \mathrm{Ma}$. The geochronological data are consistent with the emplacement relationship observed in the field, and the MD and GD are the products of another phase of magmatism after syenite facies emplacement. Furthermore, these ages are consistent with the emplacement age of the syenite (135-130 Ma), diorite, and gabbro ( 125 Ma) in the Handan area. The above discussion indicates that the Hongshan alkaline complex has experienced at least two different magmatic events: the early syenite magmatic event and the late diorite and gabbro magmatic event. The gap between the two stages of magmatism was approximately $5 \mathrm{Ma}$, and both events occurred in the Early Cretaceous in the Mesozoic. 


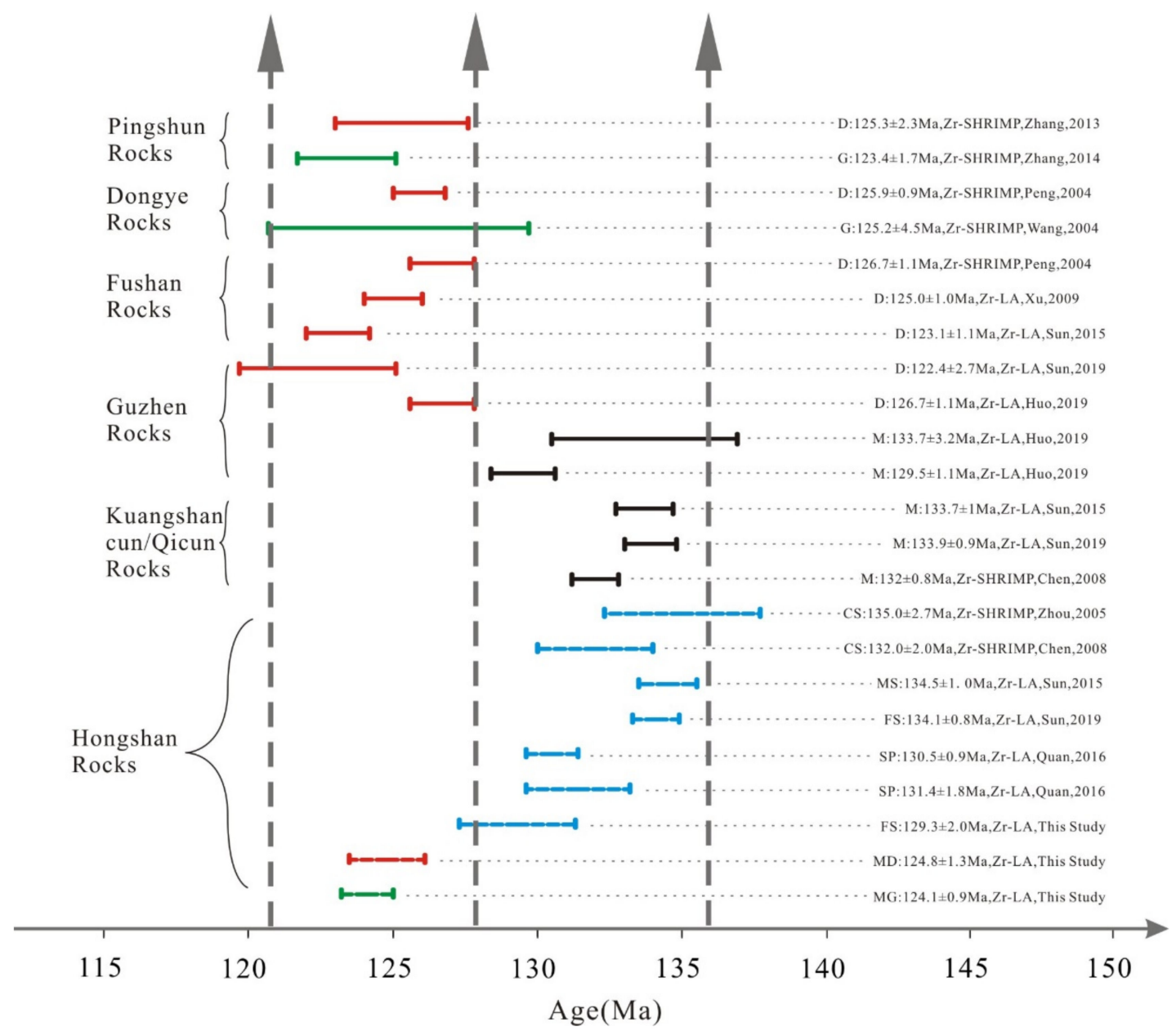

Figure 11. The ages of Mesozoic rocks from the Handan area. G: Gabbro, D: Diorite, MG: monzo-gabbro, MD: monzo-diorite, M: monzonite, CS: coarse-grained syenite, MS: medium-grained syenite, FS: fine-grained.

\subsection{Petrogenesis}

The geologic and geochronologic characteristics of the Hongshan complex suggest a multistage plutonic and hypabyssal alkaline complex. The syenite, MD, and GD have independent geochemical characteristics. Furthermore, gabbro-diorite magmatism is later than syenite magmatism. These characteristics are difficult to be explained by their origin in the evolution of homologous magma. If they are derived from the same magma evolution, syenite should be from the late magma evolution, and its formation age should be slightly later than gabbro and diorite. This is inconsistent with the dating results. Therefore, we discuss their petrogenesis separately.

\subsubsection{Petrogenesis of the Syenites}

Petrogenetic models of syenite are diverse, including (1) strong fractional crystallization of mantle-derived basaltic magma [52,53]; (2) partial melting of enriched lithospheric mantle [54,55]; (3) mixing of mantle-derived basaltic magma and crust derived melt [56,57]; and (4) partial melting of thickened continental crust (or partial melting of crustal rocks under high pressure) $[58,59]$. The syenites from Hongshan are generally high in $\mathrm{Al}^{(} \mathrm{Al}_{2} \mathrm{O}_{3}$ $=16.38-19.10 \%)$, high in $\mathrm{Sr}(356-1737 \mathrm{ppm})$, and low in $\mathrm{Yb}(0.94-2.65 \mathrm{ppm})$ and have high $\mathrm{Sr} / \mathrm{Y}$ ratios (17.45-100.55). Furthermore, the syenites have relatively low $\mathrm{MgO}$ contents $(0.09-2.56 \%)$ and are depleted in mantle-derived elements, such as Cr (Avg $=7.16 \mathrm{ppm})$, Co $(\mathrm{Avg}=6.85 \mathrm{ppm})$, and $\mathrm{Ni}(\mathrm{Avg}=9.79 \mathrm{ppm})$. It shows the geochemical properties of adakitic rocks associated with thickened lower crust (Figure 12) [60]. Experimental petrology and phase equilibrium studies show that partial melting of normal-thickness continental crust 
or the middle-upper part of thickened continental crust ( $\leq 1.0 \mathrm{GPa}, 30-40 \mathrm{~km})$ produces granitic magma, whereas partial melting of the bottom of thickened continental crust $(55-60 \mathrm{~km})$ produces syenite magma [61]. Deng (1998) divided trachyte (syenite) into a high-pressure type and a low-pressure one from the perspective of lithofacies balance. There is no plagioclase in the residual minerals of a high-pressure trachyte melt, which is equivalent to eclogite in terms of mineral assemblage. There is no Eu anomaly in such rocks. Low-pressure trachyte is the product of crystallization differentiation of basaltic magma and has an obvious negative Eu anomaly. The $\delta \mathrm{Eu}$ values of the Hongshan syenite vary from 0.72 to 1.23, and there is no obvious negative Eu anomaly. It suggests that there may not be a balance between melt and plagioclase in the magma source area of the Hongshan syenite. The magma of the Hongshan syenite was derived from partial melting under high pressure [62]. The FBAS zircons have high ${ }^{176} \mathrm{Hf} /{ }^{177} \mathrm{Hf}$ ratios $(0.282176-0.282359)$, negative $\varepsilon H f(t)$ values $(-18.3--11.8)$ and old two-stage Hf model ages $\left(\mathrm{T}_{\mathrm{DM} 2}\right)(2.68-3.26 \mathrm{Ga})$. There are Archean detrital zircons and a few Proterozoic, Paleozoic, and Mesozoic detrital zircons in the FBAS. This shows that the magma may have been derived from the partial melting of the old lower crust of the NCC, and a small amount of upper crustal overburden was incorporated during the process of magma formation and evolution.
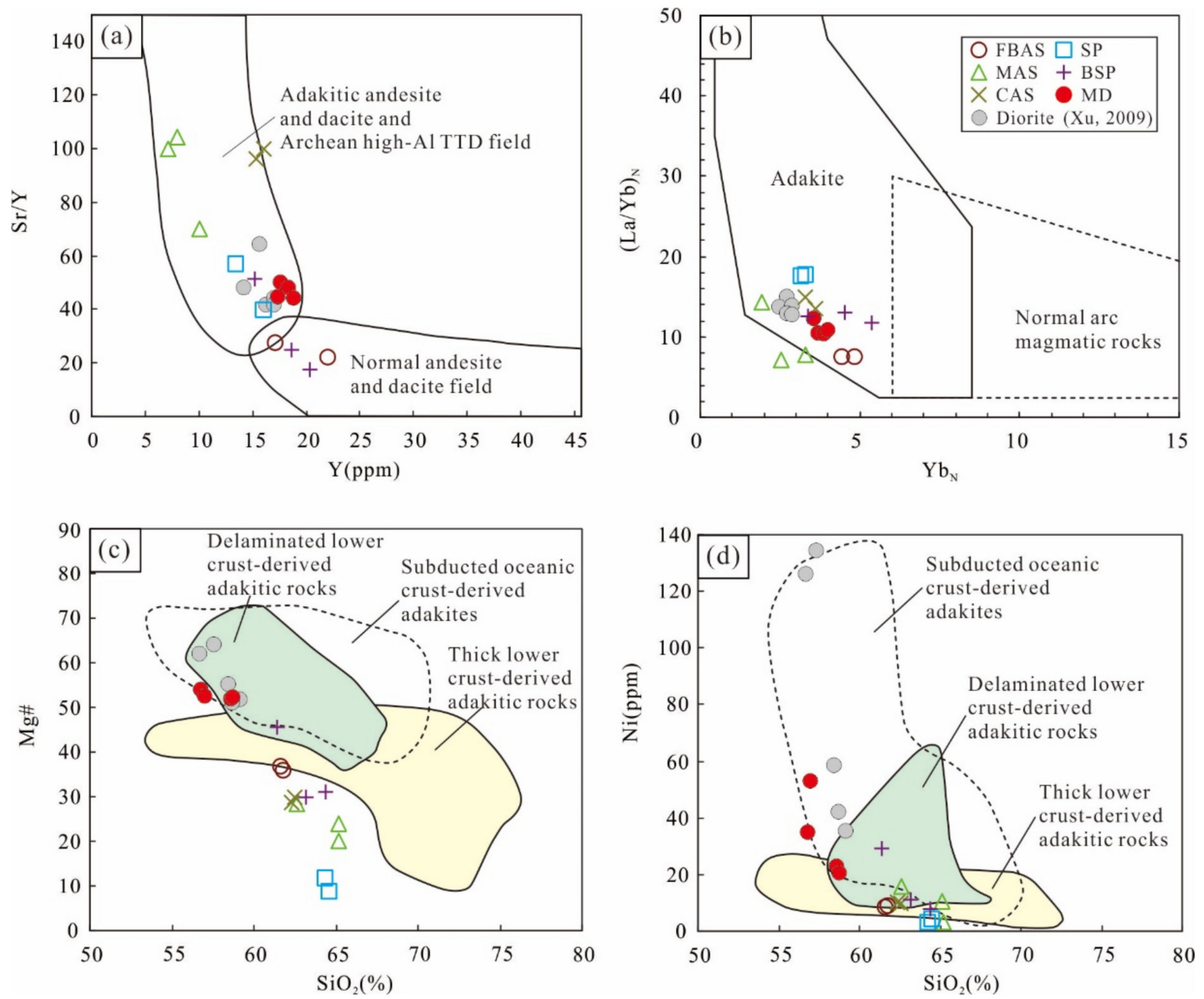

Figure 12. (a)The $\mathrm{Y}$ versus $\mathrm{Sr} / \mathrm{Y}$ and (b) the $\mathrm{Yb}$ versus $\mathrm{La} / \mathrm{Yb}$ diagrams $[63,64]$; (c) $\mathrm{The}_{\mathrm{SiO}}$ versus $\mathrm{Mg}^{\#}$ and $(\mathbf{d})$ the $\mathrm{SiO} 2$ versus Ni diagrams [65].

The difference in $\mathrm{Rb} / \mathrm{Sr}$ ratios among subtypes of the syenite group is significant. The K-rich CAS has a low value of $0.06-0.07$ close to that (0.03) of the primitive mantle [49], 
whereas Na-rich FBAS has an intermediate value of $0.10-0.11$ close to that $(0.15)$ of the continental crust [66]. Both values of CAS and FBAS are lower than the MAS, SP, and BSP (0.13-0.52). The variety in $\mathrm{Rb} / \mathrm{Sr}$ ratios among these phases is attributed to the introduction of both mantle and crustal materials into the formation of Hongshan syenite magmas, evidenced by Sr-Nd isotopic data of Hongshan syenite. The $\left({ }^{87} \mathrm{Sr} /{ }^{86} \mathrm{Sr}\right)_{t}(t=135 \mathrm{Ma})$ values of the Hongshan syenite are $0.70517-0.70735$ [37], and the $\varepsilon \mathrm{Nd}(\mathrm{t})$ values are $-11.1-$ -8.2. On the $\left({ }^{87} \mathrm{Sr} /{ }^{86} \mathrm{Sr}\right)_{\mathrm{t}}-\varepsilon \mathrm{Nd}(\mathrm{t})$ diagram (from [37]), most of the sample points from the Hongshan syenite are located on the evolution line of material exchange between the EMI-type mantle and the lower crust.

\subsubsection{Petrogenesis of the Diorite and Gabbro}

The geological and geochronological characteristics of the diorite and gabbro show that the MD is closely associated with the GD and that they are vein-emplaced syenite. Their mineral compositions and structures are different from that of the other syenites. The rock-forming mineral assemblages of the $\mathrm{MD}$ and $\mathrm{GD}$ are $\mathrm{Pl}+\mathrm{Bi}+\mathrm{Hb}+\mathrm{Or}$ and $\mathrm{Pl}+\mathrm{Hb}$, respectively. They are both classified as metaluminous and sodium series rocks. They have the same age of emplacement $(124.8 \pm 1.3 \mathrm{Ma}$ and $124.1 \pm 0.9 \mathrm{Ma})$ and have similar characteristics of major and trace elements. At the same time, they have almost the same zircon $\varepsilon H f(t)$ values $(-22.3--18.4$ and $-20.0--17.0)$, indicating that they are the products of crystallization differentiation of homologous magma or the partial melting of cognate magma to varying degrees.

Similar to the syenites, the MD from Hongshan have high Sr contents (784-892 ppm), low $\mathrm{Yb}$ contents (1.76-1.98 ppm) and high $\mathrm{Sr} / \mathrm{Y}$ ratios (44.21-49.94). Contrary, the MD has high magnesium contents $\left(\mathrm{MgO}=4.04-4.59 \%, \mathrm{Mg}^{\#}=51.4-54.0\right)$, is lower in potassium and sodium $\left(\mathrm{K}_{2} \mathrm{O}+\mathrm{Na}_{2} \mathrm{O}=7.33-9.41 \%\right)$, and are enriched in ferrophilic elements, such as Cr (35-96 ppm), Co (16.5-23.3 ppm), and Ni (21-53 ppm). In the genetic discrimination diagram of adakitic rocks, the MD samples are located in the adakite area formed by the melting of subducted oceanic plates. Rapp et al. (1999) postulated the concept of "e = effective basaltic slab melt/mantle peridotite". When e is greater than 1, basaltic slab melt forms high silicon adakite after metasomatizing mantle peridotite when passing through mantle wedge; When e is less than 1, the partial melting of mantle wedge peridotite occurs, and the melt formed is modified by slab melt to form low silicon adakite. The MD from Hongshan has low $\mathrm{SiO}_{2}(56.10-57.75 \mathrm{wt} \%)$ and high $\mathrm{TiO}_{2}(0.70-0.77 \mathrm{wt} \%)$, which is similar to the characteristics of low silicon adakite [67]. Therefore, we believe these diorites may originate from the partial melting of mantle wedge peridotite metasomatized by subduction slab melt [68,69].

Mafic magmas can be formed in oceanic ridges, ocean islands, mantle plumes, subducted island arcs, continental margins, and intracontinental deep fault environments [70]. The GD from Hongshan has low $\mathrm{SiO}_{2}$ (48.94-48.98 wt\%) and high $\mathrm{MgO}(7.84 \%-8.16 \% \mathrm{wt} \%$ ). Additionally, they show the enrichment characteristics of LILEs and LREEs and have REE patterns similar to that of arc magma [71]. The GD is strongly depleted of high field strength elements such as $\mathrm{Nb}$, Ta, and $\mathrm{Ti}$, with a high $\mathrm{Th} / \mathrm{Nb}$ ratio (0.289-0.292) and low $\mathrm{Nb} /$ La ratio (0.273-0.276), which is very similar to typical arc magma $(\mathrm{Th} / \mathrm{Nb}=0.11-2.0$, $\mathrm{Nb} / \mathrm{La}=0.15-0.63$ ) [72]. On the diagrams of the $\mathrm{Zr}$ versus Ti and Ti versus V(Figure 13a,b), the sample points are located in the range of arc magma on the active continental margin. 

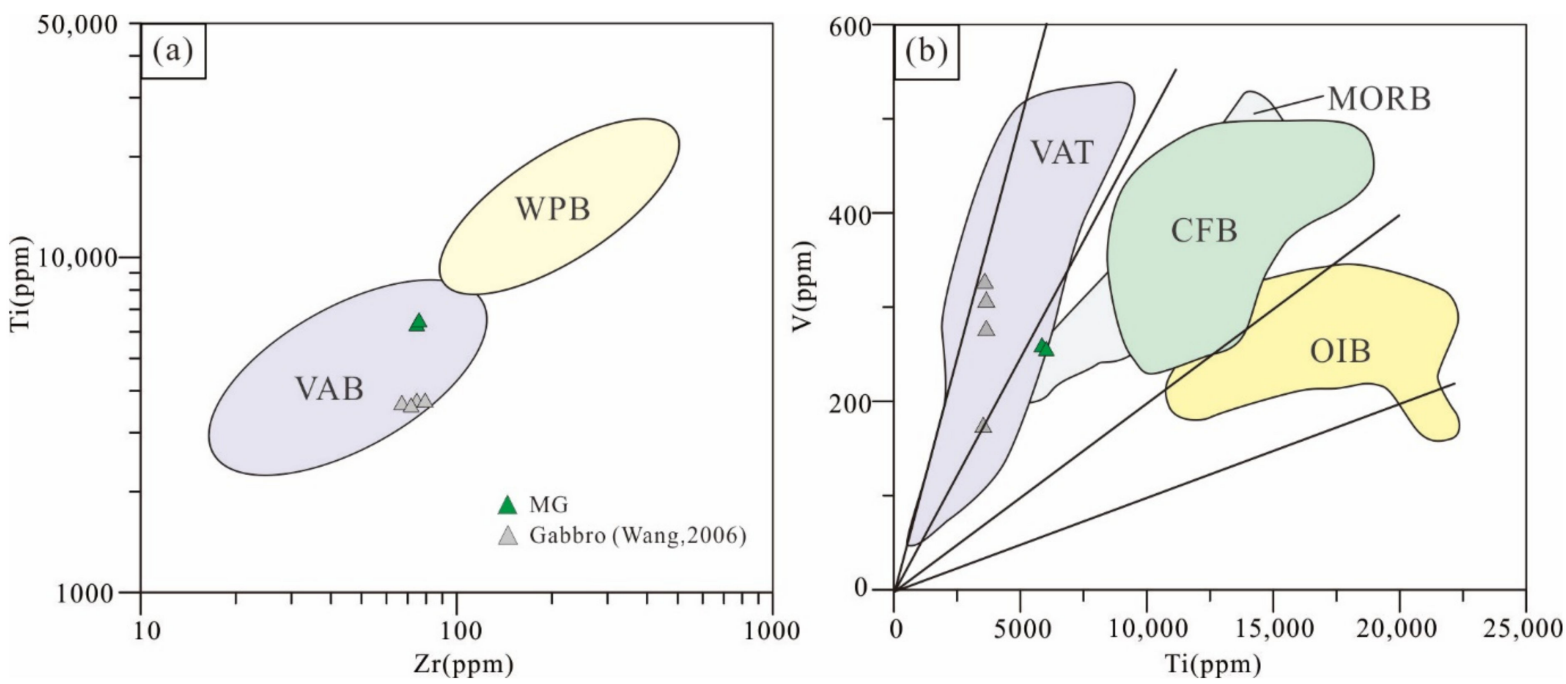

Figure 13. (a) The Zr versus Ti diagrams [73]; (b) The Ti versus V diagrams [74]. VAB: Volcanic Arc Basalt; WPB: Intra Plate Basalt; VAT: Volcanic Arc Tholeiite; CFB: Continental overflow Basalt; MORB: Mid Ocean Ridge Basalt; OIB: Ocean Island Basalt.

Both the diorite and gabbro in the Handan area have relatively high ${ }^{87} \mathrm{Sr} /{ }^{86} \mathrm{Sr}(\mathrm{t})$ values $(0.70581-0.70641,0.705012-0.705387)$ and low $\varepsilon \mathrm{Nd}(\mathrm{t})$ values $(-8.30--16.56,-12.58$ $-13.54)[39,75]$. This pattern is obviously different from the geochemical characteristics of typical oceanic crust and asthenospheric mantle, which has depleted $\mathrm{Nd}$ isotope compositions $(\varepsilon \mathrm{Nd}(\mathrm{t})$ value $>0)$ and low initial ${ }^{87} \mathrm{Sr} /{ }^{86} \mathrm{Sr}$ ratios. However, this pattern is consistent with the characteristics of mafic rocks formed in the enriched lithospheric mantle source area of the Jiaodong area [32]. It is suggested that the magma associated with the diorite and gabbro in the Handan area may have been derived from the enriched lithospheric mantle. The MD and GD have obviously low $\varepsilon H f(t)$ values (-22.3--18.4 or $-20.0--17.0)$, and the two-stage model age $\mathrm{T}_{\mathrm{DM} 2}(\mathrm{Hf})(3.6-3.1 \mathrm{Ga})$ is slightly older than that of the FBAS, indicating that the magma originated from the enriched lithospheric mantle with the characteristics of the middle Archean lower crust.

Experimental petrological studies show that the hydrous minerals phlogopite and amphibole can only exist stably in the lithospheric mantle [76]. Rb and Ba are incompatible elements in phlogopite, while $\mathrm{Rb}, \mathrm{Sr}$, and Ba are moderately compatible in amphibole [77]. This means that melts in equilibrium with amphibole should have significantly lower $\mathrm{Rb} / \mathrm{Sr}$ ratios $(<0.1)$ and higher $\mathrm{Ba} / \mathrm{Rb}$ ratios $(>20)$ than melts derived from phlogopite-bearing sources, which have extremely low Ba concentrations and $\mathrm{Ba} / \mathrm{Rb}$ values $(<20)$ [78]. The MD and GD from Hongshan have low $\mathrm{Rb} / \mathrm{Sr}$ ratios (0.01-0.06) (excluding alkali metasomatic samples) and high $\mathrm{Ba} / \mathrm{Rb}$ ratios (24.8-29.9), indicating that they may have been derived from magmas generated by the partial melting of an amphibole-bearing region of the enriched lithospheric mantle (Figure 14b). K/Yb and Dy/Yb can constrain the mantle source's composition and degree of partial melting during the generation of mafic rocks, as well as to discriminate between partial melting in the spinel and garnet stability fields of phlogopite-bearing and/or amphibole-bearing lherzolitic mantle [79,80]. Partial melts generated within the spinel stability field generally have low $\mathrm{Dy} / \mathrm{Yb}$ values $(<1.5)$, whereas partial melting in the garnet stability field produces melts with high $\mathrm{Dy} / \mathrm{Yb}$ values $(>2.5)$ (Figure 14a). The MD and GD from Hongshan have Dy/Yb ratios ranging from 1.88 to 2.07, plotting between the partial melting curves of garnet-facies amphibole lherzolite and spinel-facies amphibole lherzolite. This implies that partial melting may have taken place in the spinel-garnet transition zone. The large range of $\mathrm{K} / \mathrm{Yb}$ values suggests variable degrees of partial melting. Robinson and Wood (1998) demonstrated that the minimum pressure at which garnet is stable on the anhydrous solidus of fertile peridotitic mantle is $2.8 \mathrm{GPa}$, corresponding to a depth of approximately $85 \mathrm{~km}$, with the maximum depth of 
the spinel-garnet transition zone being 75-85 $\mathrm{km}$. This indicates that the MD and GD from Hongshan were most likely derived from partial melting of amphibole-bearing lherzolitic lithospheric mantle in the spinel-garnet transition zone at a depth of $75-85 \mathrm{~km}$.
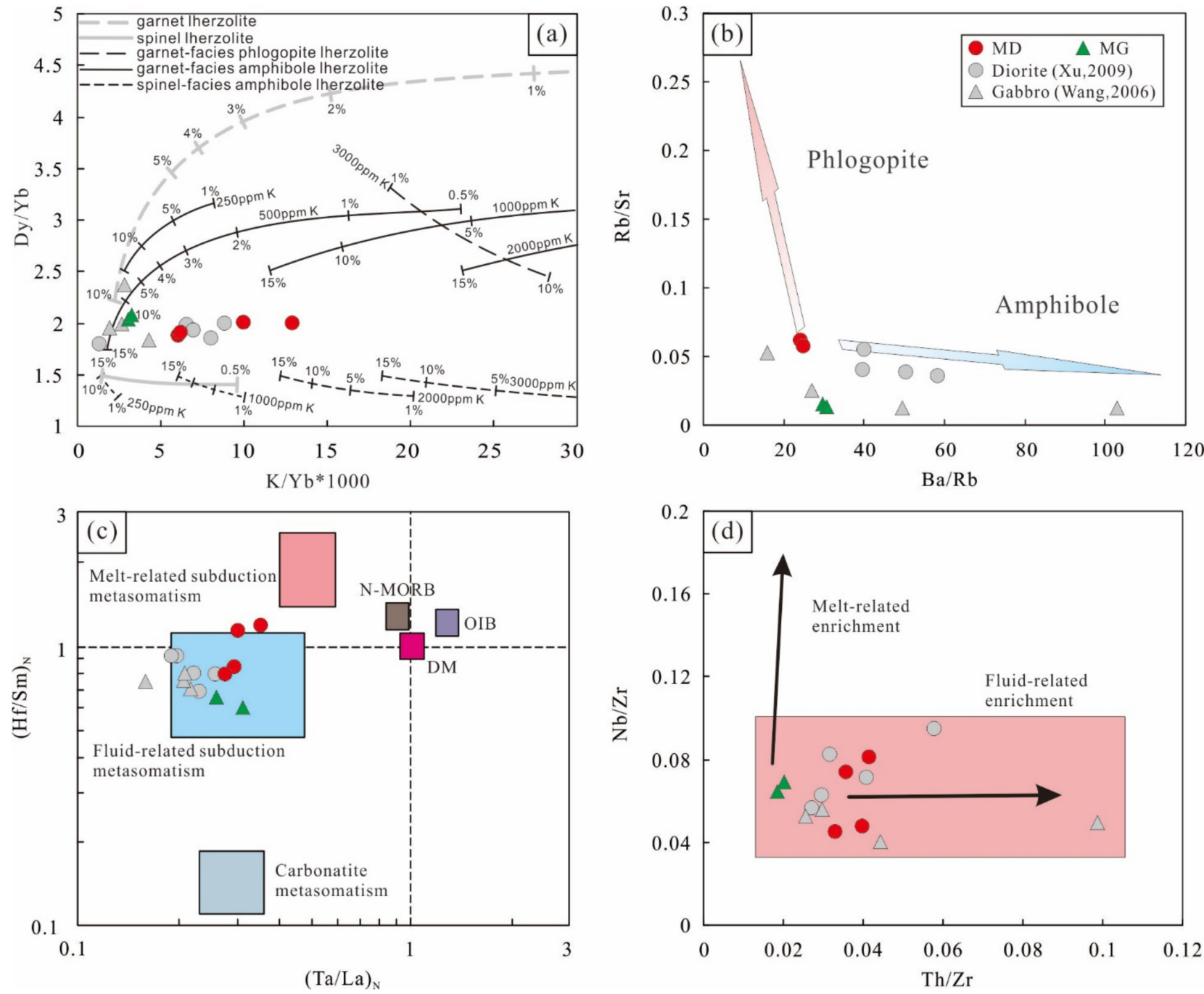

Figure 14. (a) The $\mathrm{K} / \mathrm{Yb}$ versus $\mathrm{Dy} / \mathrm{Yb}$ and $(\mathrm{b})$ the $\mathrm{Rb} / \mathrm{Sr}$ versus $\mathrm{Ba} / \mathrm{Rb}$ diagrams. Melting curves for garnet lherzolite, spinel lherzolite, garnet-facies phlogopite lherzolite, garnet-facies amphibole lherzolite and spinel-facies amphibole lherzolite are after [79]. (c) $(\mathrm{Hf} / \mathrm{Sm})_{\mathrm{N}}$ versus $(\mathrm{Ta} / \mathrm{La})_{\mathrm{N}}$ diagram [77]. (d) $\mathrm{Nb} / \mathrm{Zr}$ versus $\mathrm{Th} / \mathrm{Zr}$ diagram.

There are two main mechanisms for forming enriched lithospheric mantle endmembers by partial melting: metasomatism of melts or fluids from subducted plates and thermal alteration of volatile-rich $\left(\mathrm{CO}_{2}+\mathrm{H}_{2} \mathrm{O}\right)$ from depleted asthenosphere mantle [81,82]. Generally, the fluid-related metasomatism in the subduction process would result in the depletion of Ta and $\mathrm{Hf}$ relative to La and Sm, respectively [32]. The depletion of Ta relative to La and enrichment of $\mathrm{Hf}$ relative to $\mathrm{Sm}$ might be related to the melt-related subduction metasomatism [32]. The low Ta/La ratio and strong depletion in Hf relative to Sm are generally ascribed to the carbonatite metasomatism [83]. The MD and GD from Hongshan have low $(\mathrm{Ta} / \mathrm{La})_{\mathrm{N}}$ ratios $(0.28-0.35)$ and $(\mathrm{Hf} / \mathrm{Sm})_{\mathrm{N}}$ ratios $(0.60-1.20)$. In the diagram of $(\mathrm{Ta} / \mathrm{La})_{\mathrm{N}}-(\mathrm{Hf} / \mathrm{Sm})_{\mathrm{N}}$, the samples fall in the subduction-related fluids metasomatism (Figure 14c), indicating that the cause of metasomatism may be a fluid-related process. In addition, the diagram of $\mathrm{Th} / \mathrm{Zr}-\mathrm{Nb} / \mathrm{Zr}$ also shows the characteristics of enriched mantle modification by subducted slab-derived fluids (Figure 14d). 
The above discussion indicates that the MD and GD from Hongshan most likely originated from enriched lithospheric mantle metasomatized by slab-derived hydrous fluids. The Hongshan syenite may be originated from mixing the thickened lower crust and the enriched lithospheric mantle magma.

\subsection{Geodynamic Implications}

During the Early Cretaceous, mafic magmatism was widely developed in the eastern and central parts of the NCC (including Jiaodong, Liaodong, Luxi, Taihang Mountains, and Dabie Sulu areas) [20,32,84-86]. Accompanied by large-scale magmatic activities, the NCC also developed massive gold mineralization, a large number of metamorphic core complexes, and fault basins $[9,87]$. These strong magmatic, tectonic, and metallogenic events indicate that the NCC was in an extensional tectonic regime and lost its stability during the early Cretaceous [88].

At present, several models have been proposed to interpret the destruction process of the NCC, including delamination [2] and thermal erosion [89], which are the most widely accepted. The age and genesis of the Hongshan complex may provide some clues for understanding crust-mantle interaction and destruction mechanism, the central part of the NCC. Ma et al. (2016) explained the co-occurrence of the Early Cretaceous asthenospheric and lithospheric mantle-derived mafic rocks in the Jiaodong Peninsula by using the delamination model and considered that the Jiaodong Peninsula and the Bohai Sea were the centers of the lithospheric destruction process of NCC. The rapid and intense lithospheric delamination would trigger thermomechanical erosion within the interior domains of the NCC, such as the Taihang Mountains [86]. The geochemical characteristics of the Hongshan complex indicate that magmas have experienced two processes: partial melting of enriched lithospheric mantle and subsequent mixing with thickened lower crust. In the delamination model, melts of the delaminated lower crust will inevitably interact with the mantle peridotite while migrating upward, resulting in elevated $\mathrm{MgO}, \mathrm{Cr}$, and $\mathrm{Ni}$ concentrations $[2,90]$. As mentioned above, the low $\mathrm{MgO}$ contents and depleted in $\mathrm{Cr}, \mathrm{Co}$, and $\mathrm{Ni}$ of Hongshan syenites indicate that it originated from partial melting of the thickened lower crust caused by thermal erosion. It is generally accepted that the destruction of the NCC in the Early Cretaceous was related to the subduction of the Paleo-Pacific plate $[2,8,10]$. Some studies suggest that the subduction of the Paleo-Pacific plate did not affect the central part of the NCC because of too far away from the coastline, more than $1000 \mathrm{~km}$. However, recent geophysical data show that horizontal subduction of the Paleo-Pacific plate is trapped in the mantle transition zone under the craton [54,91]. The influence of horizontal plate subduction can be as far as $2000 \mathrm{~km}$. Suppose the huge extension of eastern China since Mesozoic and the distance of Japan Sea formed in Cenozoic are removed. In that case, the distance between Taihang Mountain and the ancient Pacific subduction zone should be less than $2000 \mathrm{~km}[37,92]$. The MD and GD in Hongshan are the products of partial melting of lithospheric mantle metasomatized by subducted slab fluid, which corresponds to the subduction of the Paleo-Pacific plate in the central NCC.

Combining the geological, geochronological, geochemical, and isotopic features, we propose a model to interpret the petrogenesis of the Hongshan complex (Figure 15). Along with the subduction of the Paleo-Pacific plate to the east of Eurasia in the Late Triassic [93], the slab-released fluid modified the overlying mantle. It transformed the Paleozoic cratonic lithospheric mantle to Mesozoic enriched lithospheric mantle. In the Early Cretaceous, the roll-back of the Paleo-Pacific plate led to an extremely extensional environment in the NCC. The enriched lithospheric mantle was heated by upwelling asthenosphere and then partial melting to form the widespread mafic magma chamber in the NCC at a depth of 75-80 km. The magmatic emplacement process resulted in partial melting of the overlying thickened lower crust. Finally, the mixed magma emplaced and formed Hongshan syenite. 

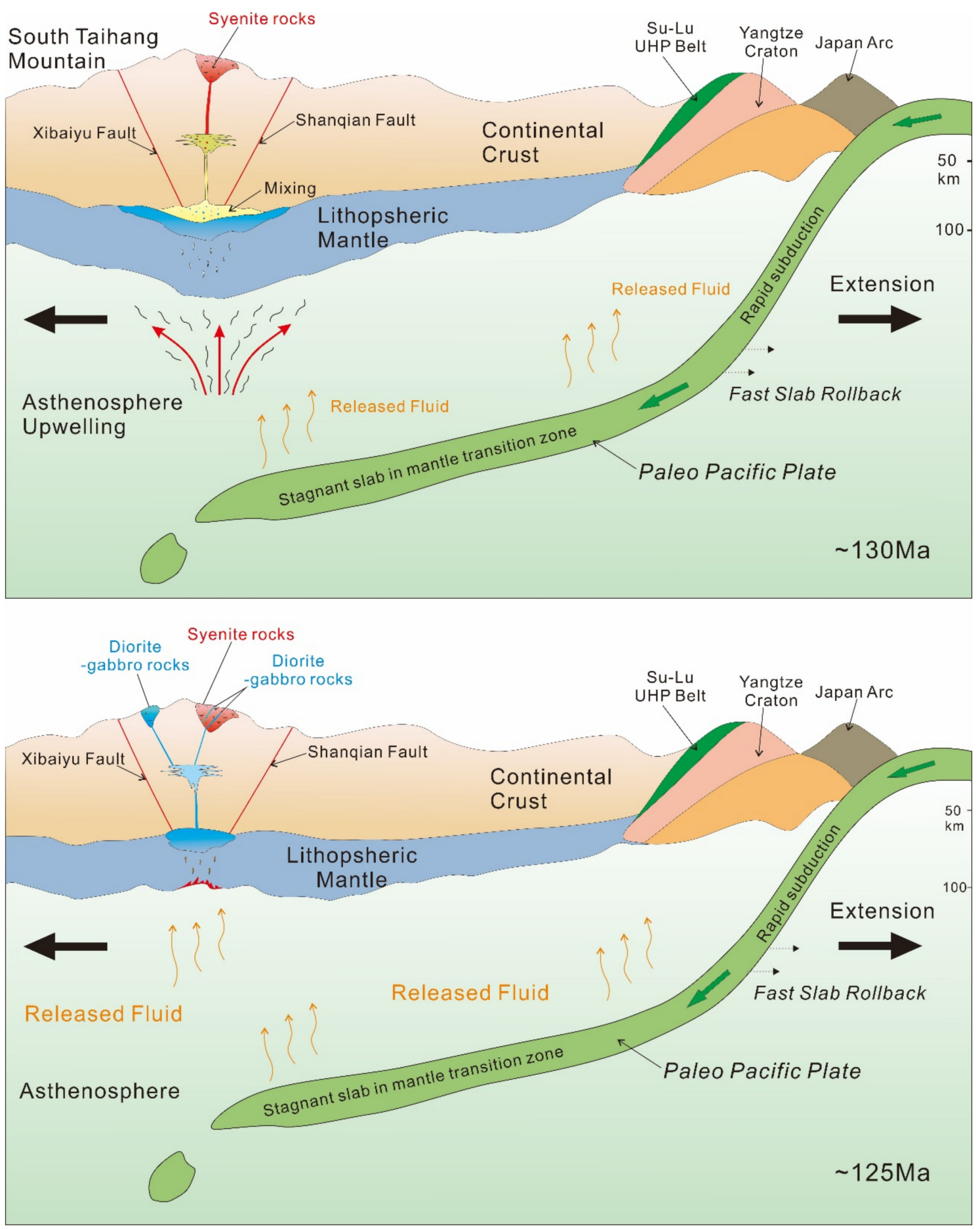

Figure 15. Tectonic model for the generation and emplacement of the Hongshan complex in the southern Taihang Mountains (modified after [87]).

\section{Conclusions}

The Hongshan rocks are mainly composed of syenite (including the FBAS, MAS, CAS, SP, and BSP), diorite (the MD), and gabbro (the GD). Zircon U-Pb chronology shows that the syenite and the diorite-gabbro emplacements occurred at $130 \mathrm{Ma}$ and $\sim 125 \mathrm{Ma}$, respectively. Field geology, petrology, and element geochemistry demonstrate that the parental magmas of Hongshan syenite originated from the mixture of partially melted thickened lower crust and partially melted lithospheric mantle. The Hongshan diorite and gabbro magma most likely originated from enriched lithospheric mantle metasomatized 
by slab-derived hydrous fluids. They all formed in an extensional environment associated with the subduction and roll-back of the Paleo-Pacific plate beneath the North China plate in the Early Cretaceous.

Author Contributions: Conceptualization, X.C. and J.S.; methodology, X.Z.; software, L.M.; validation, F.S. and Y.L.; formal analysis, K.Z.; investigation, F.S. and Y.L.; resources, L.M.; data curation, Y.L.; writing—original draft preparation, X.C.; writing—review and editing, J.S.; visualization, Y.M.; supervision, J.S. and Y.M.; project administration, X.Z.; funding acquisition, J.S. and Y.M. All authors have read and agreed to the published version of the manuscript.

Funding: This research was funded by the National Key Research and Development Program of China (Grant No. 2017YFC0601306) and the Program of the China Geological Survey (Grant No. DD20190368), as well as the Self-determined Foundation of Key Laboratory of Mineral Resources Evaluation in Northeast Asia, Ministry of Natural Resources, Changchun, China (Grant No. DBY-ZZ-19-27).

Acknowledgments: We appreciate Xiaolei Peng of Jilin University, Captain Zhong Li of No. 1 Geological Team of Hebei Bureau of Geological Exploration and Development, and his colleagues Yucheng Li, Hao Chang, Liangliang Zhang for their help in fieldwork.

Conflicts of Interest: No conflict of interest exists in submitting this manuscript, and all authors approve the manuscript for publication. I would like to declare on behalf of my co-authors that the work described was original research that has not been published previously and is not under consideration for publication elsewhere, in whole or in part. All the authors listed have approved the manuscript that is enclosed.

\section{References}

1. Zhao, G.C.; Zhai, M.G. Lithotectonic elements of Precambrian basement in the North China Craton: Review and tectonic implications. Gondwana Res. 2013, 23, 1207-1240. [CrossRef]

2. Gao, S.; Rudnick, R.L.; Yuan, H.L.; Liu, X.M.; Liu, Y.S.; Xu, W.L.; Ling, W.L.; Ayers, J.; Wang, X.C.; Wang, Q.H. Recycling lower continental crust in the North China craton. Nature 2004, 432, 892-897. [CrossRef]

3. Zhu, R.X.; Xu, Y.G.; Zhu, G.; Zhang, H.F.; Xia, Q.K.; Zheng, T.Y. Destruction of the North China Craton. Sci. China Earth Sci. 2012, 42,1135-1159, (in Chinese with English abstract). [CrossRef]

4. Guo, F. The modification of the lithospheric mantle beneath the North China Craton by subducted continental and oceanic crust: Oxygen isotopic records of olivine. Acta Petrol. Mineralogica. 2013, 32, 593-603, (in Chinese with English abstract).

5. Deng, J.F.; Mo, X.X.; Zhao, H.L.; Wu, Z.X.; Luo, Z.H.; Su, S.G. A new model for the dynamic evolution of Chinese lithosphere: 'continental roots-plume tectonics'. Earth Sci. Rev. 2004, 65, 223-275. [CrossRef]

6. Kusky, T.M.; Windley, B.F.; Zhai, M.G. Tectonic evolution of the North China Block: From orogen to craton to orogen. Geol. Soc. Lond. Spec. Publ. 2007, 280, 1-34. [CrossRef]

7. Zhai, M.G.; Fan, Q.C.; Zhang, H.F.; Sui, J.L.; Shao, J.A. Lower crustal processes leading to Mesozoic lithospheric thinning beneath eastern North China: Underplating, replacement and delamination. Lithos 2007, 96, 36-54. [CrossRef]

8. Zhu, R.X.; Yang, J.H.; Wu, F.Y. Timing of destruction of the North China Craton. Lithos 2012, 149, 51-60. [CrossRef]

9. Gao, S.; Rudnick, R.L.; Carlson, R.W.; McDonough, W.F.; Liu, Y.S. Re-Os evidence for replacement of ancient mantle lithosphere beneath the North China craton. Earth Planet. Sci. Lett. 2002, 198, 307-322. [CrossRef]

10. Wu, F.Y.; Ge, W.C.; Sun, D.Y.; Guo, C.L. Discussions on the lithospheric thinning in eastern China. Earth Sci. Front. 2003, 10, 51-60, (in Chinese with English abstract).

11. Zhang, H.F.; Ying, J.F.; Xu, P.; Ma, Y.G. Mantle olivine xenocrysts entrained in Mesozoic basalts from the North China craton:Implication for replacement process of lithospheric mantle. Chin. Sci. Bull. 2004, 49, 961-966. [CrossRef]

12. Xu, W.L.; Gao, S.; Wang, Q.H.; Wang, D.Y.; Liu, Y.S. Mesozoic crustal thickening of the eastern North China craton:Evidence from eclogite xenoliths and petrologic implications. Geol. Soc. Am. 2006, 34, 721-724.

13. Luo, Z.H.; Deng, J.F.; Han, X.Q. On Characteristics of Magmatic Activities and Orogenic Process of Taihangshan Intraplate Orogen; Geological Publishing House: Beijing, China, 1999; pp. 1-124. (in Chinese)

14. Chen, B.; Liu, C.Q.; Tian, W. Magma-mixing between mantle- and crustal-derived melts in the process of Mesozoicmagmatism, Taihangshan: Constraints from petrology and geochemistry. Earth Sci. Front. 2006, 13, 140-147, (in Chinese with English abstract).

15. Sørensen, H. The Alkaline Rocks; John Wiley and Sons: London, UK, 1974.

16. Queen, M.; Hanes, J.A.; Archibald, D.A.; Farrar, E.; Heaman, L.M. ${ }^{40} \mathrm{Ar} /{ }^{39} \mathrm{Ar}$ phlogopite and U -Pb perovskite dating of lamprophyre dykes from the eastern Lake Superior region: Evidence for a 1.14 Ga magmatic precursor to Midcontinent Rift volcanism. Can. J. Earth Sci. 1996, 33, 958-965. [CrossRef]

17. Ren, K.X. Study progress of the alkaline rocks: A review. Geol. Chenical Miner. 2003, 25, 151-163. 
18. Tappe, S.; Foley, S.F.; Jenner, G.A.; Heaman, L.M.; Kjarsgaard, B.A.; Romer, R.L.; Stracke, A.; Joyce, N.; Hoefs, J. Genesis of ultramafic lamprophyres and carbonatites at aillik bay, labrador: A Consequence of incipient lithospheric thinning beneath the North Atlantic Craton. J. Petrol. 2006, 47, 1261-1315. [CrossRef]

19. Ma, L.; Jiang, S.Y.; Hofmann, A.W.; Xu, Y.G.; Hou, M.L. Rapid lithospheric thinning of the north china craton: New evidence from cretaceous mafic dikes in the jiaodong peninsula. Chem. Geol. 2016, 432, 1-15. [CrossRef]

20. Wang, L.X.; Marks, M.A.W.; Wenzel, T.; Markl, G. Halogen-bearing minerals from the tamazeght complex (morocco): Constraints on halogen distribution and evolution in alkaline to peralkaline magmatic systems. Can. Mineral. 2016, 54, 1347-1368. [CrossRef]

21. Marks, M.A.W.; Markl, G. A global review on agpaitic rocks. Earth Sci. Rev. 2017, 173, 229-258. [CrossRef]

22. Cai, J.H.; Yan, G.H.; Xiao, C.D.; Wang, G.Y.; Mu, B.L.; Zhang, R.H. Nd, Sr, Pb isotopic characteristics of the Mesozoic intrusive rocks in the Taihang-Da Hinggan Mountains Tectonomagmatic Belt and their source region. Acta Petrol. Sin. 2004, 20, 1225-1242, (in Chinese with English abstract).

23. Chen, B.; Tian, W.; Jahn, B.M.; Chen, Z.C. Zircon SHRIMP U-Pb ages and in-situ Hf isotopic analysis for the Mesozoic intrusions in South Taihang, North China craton: Evidence for hybridization between mantle-derived magmas and crustal components. Lithos 2008, 102, 118-137. [CrossRef]

24. Yang, J.H.; O’Reilly, S.; Walker, R.J.; Griffin, W.; Wu, F.Y.; Zhang, M.; Pearson, N. Diachronous decratonization of the Sino-Korean craton: Geochemistry of mantle xenoliths from North Korea. Geology 2010, 38, 799-802. [CrossRef]

25. Xu, W.; Liu, F.L. Geochronological and geochemical insights into the tectonic evolution of the Paleoproterozoic Jiao-Liao-Ji Belt, Sino-Korean Craton. Earth Sci. Rev. 2019, 193, 162-198. [CrossRef]

26. Liu, D.Y.; Nutman, A.P.; Compston, W.; Wu, J.S.; Shen, Q.H. Remnants of $\geq 3800$ Ma crust in the Chinese part of the Sino-Korean craton. Geology 1992, 20, 339-342. [CrossRef]

27. Zhao, G.C.; Sun, M.; Wilde, S.A.; Li, S.Z. Assembly, accretion and breakup of the Paleo-Mesoproterozoic Columbia Supercontinent: Records in the North China Craton. Gondwana Res. 2003, 6, 417-434. [CrossRef]

28. Santosh, M. Assembling North China Craton within the Columbia supercontinent: The role of double-sided subduction. Precambrian Res. 2010, 178, 149-167. [CrossRef]

29. Kusky, T.M. Geophysical and geological tests of tectonic models of the North China Craton. Gondwana Res. 2011, 20 , 26-35. [CrossRef]

30. Zhai, M.G.; Santosh, M. Metallogeny of the North China Craton: Link with secular changes in the evolving Earth. Gondwana Res. 2013, 24, 275-297. [CrossRef]

31. Ma, L.; Jiang, S.Y.; Hofmann, A.W.; Dai, B.Z.; Hou, M.L.; Zhao, K.D.; Chen, L.H.; Li, J.W.; Jiang, Y.H. Lithospheric and asthenospheric sources of lamprophyres in the Jiaodong Peninsula: A consequence of rapid lithospheric thinning beneath the North China Craton? Geochim. Cosmochim. Acta 2014, 124, 250-271. [CrossRef]

32. Ma, J.Q. Metallogenic specialization of magmatic rocks as discussed in the light of endogenic deposits. Geol. Rev. 1987, 33, 84-90, (in Chinese with English abstract).

33. Song, X.Y.; Feng, Z.Y. Minor element geochemistry of mesozoic magmatic intrusions of southern taihang mountains. J. Geol. Min. Res. North China 1999, 14, 1-17, (in Chinese with English abstract).

34. Luo, Z.H.; Wei, Y.; Xin, H.T.; Ke, S.; Li, W.T.; Li, D.D.; Huang, J.X. The Mesozoic intraplate orogeny of the Taihang Mountains and the thinning of the continental lithosphere in North China. Earth Sci. Front. 2006, 13, 52-63, (in Chinese with English abstract).

35. Sun, Y.; Xiao, L.; Zhan, Q.Y.; Wu, J.X.; Zhu, D.; Huang, W.; Bai, M.; Zhang, Y.H. Petrogenesis of the Kuangshancun and Hongshan intrusive complexes from the Handan-Xingtai district: Implications for iron mineralization associated with Mesozoic magmatism in the North China Craton. J. Asian Earth Sci. 2015, 113, 1162-1178. [CrossRef]

36. Sun, Y.; Wu, T.; Xiao, L.; Bai, M.; Zhang, Y.H. U-Pb ages, Hf-O isotopes and trace elements of zircons from the ore-bearing and ore-barren adakitic rocks in the Handan-Xingtai district: Implications for petrogenesis and iron mineralization. Ore Geol. Rev. 2019, 104, 14-25. [CrossRef]

37. Chen, B.; Jahn, B.M.; Arakawa, Y.; Zhai, M.G. Petrogenesis of the Mesozoic intrusive complexes from the southern Taihang Orogen, North China Craton: Elemental and Sr-Nd-Pb isotopic constraints. Contrib. Miner. Pet. 2004, 148, 489-501. [CrossRef]

38. Xu, W.L.; Lin, J.Q. The magmatic evolution of Hb-diorite series of Yanshan stage in Han-Xing district, China-The amphiboledominated fractional crystallization. J. Chang. Univ. Earth Sci. 1990, 20, 259-264.

39. Xu, W.L.; Yang, D.B.; Pei, F.P.; Yu, Y. Petrogenesis of Fushan high-Mg\# diorites from the southern Taihang Mts. In the central North China Craton:Resulting from interaction of peridotite-melt derived from partial melting of delaminated lower continental crust. Acta Petrol. Sin. 2009, 25, 1947-1961, (in Chinese with English abstract).

40. Yuan, H.L.; Gao, S.; Liu, X.M.; Li, H.M.; Günther, D.; Wu, F.Y. Accurate U-Pb age and trace element determinations of zircon by laser ablation-inductively coupled plasma-mass spectrometry. Geostand. Geoanalytical Res. 2004, 28, 353-370. [CrossRef]

41. Andersen, T. Correction of common lead in U-Pb analyses that do not report $204 \mathrm{~Pb}$. Chem. Geol. 2002, 192, 59-79. [CrossRef]

42. Zhang, S.H.; Zhao, Y.; Li, X.H.; Ernst, R.E.; Yang, Z.Y. The 1.33-1.30 Ga Yanliao large igneous province in the North China Craton: Implications for reconstruction of the Nuna (Columbia) supercontinent, and specifically with the North Australian Craton. Earth Planet. Sci. Lett. 2017, 465, 112-125. [CrossRef]

43. Hu, Z.C.; Zhang, W.; Liu, Y.S.; Gao, S.; Li, M.; Zong, K.Q.; Chen, H.H.; Hu, S.H. "Wave" signal-smoothing and mercury-removing device for laser ablation quadrupole and multiple collector ICPMS analysis: Application to lead isotope analysis. Anal. Chem. 2015, 87, 1152-1157. [CrossRef] 
44. Hu, Z.C.; Liu, Y.S.; Gao, S.; Liu, W.G.; Yang, L.; Zhang, W.; Tong, X.R.; Lin, L.; Zong, K.Q.; Li, M.; et al. Improved in situ Hf isotope ratio analysis of zircon using newly designed $X$ skimmer cone and Jet sample cone in combination with the addition of nitrogen by laser ablation multiple collector ICP-MS. J. Anal. At. Spectrom. 2012, 27, 1391-1399. [CrossRef]

45. Middlemost, E.A.K. Naming materials in the magma/igneous rock system. Earth Sci. Rev. 1994, 37, 215-224. [CrossRef]

46. Wright, J.B. A simple alkalinity ratio and its application to questions of non-orogenic granite genesis. Geol. Mag. 1969, 106, 370-384. [CrossRef]

47. Maniar, P.D.; Piccoli, P.M. Tectonic discrimination of granitoids. Geol. Soc. Am. Bull. 1989, 101, 635-643. [CrossRef]

48. Middlemost, E. A simple classification of volcanic rocks. Bull. Volcanol. 1972, 36, 382-397. [CrossRef]

49. Sun, S.S.; McDonough, W.F. Chemical and isotopic systematics of oceanic basalts: Implications for mantle composition and processes. In Magmatism in the Oceanic Basalts; Saunders, A.D., Norry, M.J., Eds.; Geological Society Special Publication: London, UK, 1989; pp. 313-345.

50. Yang, J.H.; Wu, F.Y.; Wilde, S.A.; Xie, L.W.; Yang, Y.H.; Liu, X.M. Tracing magma mixing in granite genesis: In situ u-pb dating and hf-isotope analysis of zircons. Contrib. Mineral. Petrol. 2007, 153, 177-190. [CrossRef]

51. Chen, B.; Tian, W.; Zhai, M.G.; Arakawa, Y. Zircon U-Pb geochronology and geochemistry of the Mesozoic magmatism in the Taihang Mountains and other places of the North China craton, with implications for petrogenesis and geodynamic setting. Acta Petrol. Sin. 2005, 21, 13-24, (in Chinese with English abstract).

52. Litvinovsky, B.A.; Jahn, B.M.; Zanvilevich, A.N.; Saunders, A.; Poulain, S.; Kuzmin, D.V.; Reichow, M.K.; Titov, A.V. Petrogenesis of syenite-granite suites from the Bryansky Complex (Transbaikalia, Russia): Implications for the origin of A-type granitoid magmas. Chem. Geol. 2002, 189, 105-133. [CrossRef]

53. Wang, Q.; Li, J.W.; Jian, P.; Zhao, Z.H.; Xiong, X.L.; Bao, Z.W.; Xu, J.F.; Li, C.F.; Ma, J.L. Alkaline syenites in eastern Cathaysia (South China): Link to permian-triassic transtension. Earth Planet. Sci. Lett. 2005, 230, 339-354. [CrossRef]

54. Sutcliffe, R.H.; Smith, A.R.; Doherty, W.; Barnett, R.L. Mantle derivation of Archean amphibole-bearing granitoids and associated mafic rocks: Evidence from the southern Superrior Province, Canada. Contrib. Mineral. Petrol. 1990, 105, 255-274. [CrossRef]

55. Lynch, D.J.; Musselman, T.E.; Gutmann, J.T.; Patchett, P.J. Isotopic evidence for the origin of Cenozoic volcanic rocks in the Pinacate volcanic field, northwestern Mexico. Lithos 1993, 29, 295-302. [CrossRef]

56. Mingram, B.; Trumbull, R.B.; Littman, S.; Gerstenberger, H. A petrogenetic study of anorogenic felsic magmatism in the Cretaceous Paresis ring complex, Namibia: Evidence for mixing of crust and mantle-derived components. Lithos 2000, 54, 1-22. [CrossRef]

57. Vernikovsky, V.A.; Pease, V.L.; Vernikovskaya, A.E.; Romanov, A.P.; Gee, D.G.; Travin, A.V. First report of early Triassic A-type granite and syenite intrusions from Taimyr: Product of the northern Eurasian superplume? Lithos 2003, 66, 23-36. [CrossRef]

58. Lubala, R.T.; Frick, C.; Rogers, J.H.; Walraven, F. Petrogenesis of syenites and granites of the schiel alkaline complex, Northern Transvaal, South Africa. J. Geol. 1994, 102, 307-316. [CrossRef]

59. Yang, J.H.; Chung, S.L.; Wilde, S.A.; Wu, F.Y.; Chu, M.F.; Lo, C.H.; Fan, H.R. Petrogenesis of post-orogenic syenites in the Sulu Orogenic Belt, East China: Geochronological, geochemical and Nd-Sr isotopic evidence. Chem. Geol. 2005, 214, 99-125. [CrossRef]

60. Drummond, M.S.; Defant, M.J.; Kepezhinskas, P.K. Petrogenesis of slab-derived tronhjemite-tonalite-dacite/adakite magmas. Trans. R. Soc. Edinb. Earth Sci. 1996, 87, 205-215.

61. Wyllie, P.J. Constraints imposed by experimental petrology on possible and impossible magma sources and products. Philos. Trans. R. Society. Lond. 1984, A310, 439-456.

62. Deng, J.F.; Luo, Z.H.; Zhao, H.L. Trachyte and syenite: Petrogenesis constrained by the petrological phase equilibrium. In Proceedings of the Collected Words of International Symposium on Geological Science by Department of Geology, Peking University: Beijing, China; Seism Publishing House: Beijing, China, 1998; pp. 745-757.

63. Defant, M.J.; Drummond, M.S. Derivation of some modern arc magmas by melting of young subducted lithosphere. Nature 1990, 347, 662-665. [CrossRef]

64. Martin, H. Adakitic magmas: Modern analogues of Archaean granitoids. Lithos 1999, 46, 411-429. [CrossRef]

65. Defant, M.J.; Jackson, T.E.; Drummond, M.S.; de Boer, J.Z.; Bellon, H.; Feigenson, M.D.; Maury, R.C.; Stewart, R.H. The geochemistry of young volcanism throughout western Panama and southeastern Costa Rica: An overview. J. Geol. Soc. 1992, 149, 569-579. [CrossRef]

66. Rudnick, R.L.; Fountain, D.M. Nature and composition of the continental crust: A lower crustal perspective. Rev. Geophys. 1995, 33, 267. [CrossRef]

67. Martin, H.; Smithies, R.H.; Rapp, R.; Moyen, J.F.; Champion, D. An overview of adakite, tonalite-trondhjemite-granodiorite (TTG), and sanukitoid: Relationships and some implications for crustal evolution. Lithos 2005, 79, 1-24. [CrossRef]

68. Kepezhinskas, P.K.; Defant, M.J.; Drummond, M.S. Na metasomatism in the sub-arc mantle by slab melt-peridotite interaction: Evidence from mantle xenoliths in the North Kamchatka Arc. J. Petrol. 1995, 36, 1505-1527.

69. Defant, M.J.; Xu, J.F. Adakites: Some variations on a theme. Acta Petrol. Sin. 2002, 18, 129-142.

70. Zheng, F.; Dai, L.Q.; Zhao, Z.F.; Zheng, Y.F.; Ma, L.T.; Fang, W. Syn-exhumation magmatism during continental collision: Geochemical evidence from the early Paleozoic Fushui mafic rocks in the Qinling orogen, Central China. Lithos 2020, 352-353, 1-15. [CrossRef]

71. Tamura, Y.; Ishizuka, O.; Stern, R.J. Mission immiscible: Distinct subduction components generate two primary magmas at pagan volcano, Mariana arc. J. Petrol. 2014, 55, 63-101. [CrossRef] 
72. Kimura, J.I.; Yoshida, T. Contributions of slab fluid, mantle wedge and crust to the origin of quaternary lavas in the NE Japan arc. J. Petrol. 2006, 47, 2185-2232. [CrossRef]

73. Pearce, J.A.; Norry, M.J. Petrogenetic implications of Ti, Zr, Y, and Nb variations in volcanic rocks. Contrib. Mineral. Petrol. 1979, 69, 33-47. [CrossRef]

74. Shervais, J.W. Ti-V plots and the petrogenesis of modern and ophiolitic lavas. Earth Planet. Sci. Lett. 1982, 59, 101-118. [CrossRef]

75. Wang, Y.J.; Fan, W.M.; Zhang, H.F.; Peng, T.P. Early Cretaceous gabbroic rocks from the Taihang Mountains:Implications for a paleosubduction-related lithospheric mantle beneath the central North China Craton. Lithos 2006, 86, 281-302. [CrossRef]

76. Olafsson, M.; Eggler, D.H. Phase relations of amphibolem, amphibole-carbonate and phlogopite-carbonate peridotite:petrological constrains on the asthenosphere. Earth Planet. Sci. Lett. 1983, 64, 305-315. [CrossRef]

77. LaTourrette, T.; Hervig, R.L.; Holloway, J.R. Trace element partitioning between amphibole, phlogopite, and basanite melt. Earth Planet. Sci. Lett. 1995, 135, 13-30. [CrossRef]

78. Furman, T.; Graham, D. Erosion of lithospheric mantle beneath the East African Rift system: Geochemical evidence from the Kivu volcanic province. Lithos 1999, 48, 237-262. [CrossRef]

79. Duggen, S.; Hoernle, K.; den Van, B.P.; Garbeschönberg, D. Post-Collisional transition from Subduction- to Intraplate-type Magmatism in the Westernmost Mediterranean:evidence for Continental-Edge delamination of subcontinental lithosphere. J. Petrol. 2005, 46, 1155-1201. [CrossRef]

80. Jiang, Y.H.; Jiang, S.Y.; Ling, H.F.; Ni, P. Petrogenesis and tectonic implications of Late Jurassic shoshonitic lamprophyre dikes from the Liaodong Peninsula, NE China. Mineral. Petrol. 2010, 100, 127-151. [CrossRef]

81. Chen, B.; Zhai, M.G.; Shao, J.A. Origin and significance of Mesozoic lithofacies in the northern part of Taihang Mountain: Main and trace element geochemical evidence. Sci. China 2002, 32, 896-907, (In Chinese with English abstract).

82. Lustrino, M.; Dallai, L.; Rome. On the origin of EM-I end-member. Neues Jahrb. Mineral. Abh. 2003, 179, 85-100. [CrossRef]

83. La Flèche, M.R.; Camiré, G.; Jenner, G.A. Geochemistry of post-acadian, carboniferous continental intraplate basalts from the Maritimes Basin, Magdalen Islands, Québec, Canada. Chem. Geol. 1998, 148, 115-136. [CrossRef]

84. Sun, J.F.; Zhang, J.H.; Yang, J.H.; Yang, Y.H.; Chen, S. Tracing magma mixing and crystal-melt segregation in the genesis of syenite with mafic enclaves: Evidence from in situ zircon Hf-O and apatite Sr-Nd isotopes. Lithos 2019, 334, 42-57. [CrossRef]

85. Yang, H.T.; Yang, D.B.; Mu, M.S.; Wang, A.Q.; Quan, Y.K.; Hao, L.R.; Xu, W.L.; Yang, D.H. Sr-Nd-Hf isotopic compositions of lamprophyres in western Shandong, China: Implications for the nature of the early cretaceous lithospheric mantle beneath the eastern North China Craton. Lithos 2019, 336-337, 1-13. [CrossRef]

86. Xue, F.; Santosh, M.; Tsunogae, T.; Yang, F. Geochemical and isotopic imprints of early cretaceous mafic and felsic dyke suites track lithosphere-asthenosphere interaction and craton destruction in the North China Craton. Lithos 2019, 326-327, 174-199. [CrossRef]

87. Yang, K.F.; Fan, H.R.; Santosh, M.; Hu, F.F.; Wilde, S.A.; Lan, T.G.; Lu, L.N.; Liu, Y.S. Reactivation of the Archean lower crust:implications for zircon geochronology, elemental and Sr-Nd-Hf isotopic geochemistry of late Mesozoic granitoids from northwestern Jiaodong Terrain, the North China Craton. Lithos 2012, 146-147, 112-127. [CrossRef]

88. Yang, J.H.; Wu, F.Y.; Wilde, S.A.; Belousova, E.; Griffin, W.L. Mesozoic decratonization of the North China block. Geology 2008, 36, 467-470. [CrossRef]

89. Xu, Y.G. Thermo-tectonic destruction of the archaean lithospheric keel beneath the sino-Korean Craton in China: Evidence, timing and mechanism. Phys. Chem. Earth Part A Solid Earth Geod. 2001, 26, 747-757. [CrossRef]

90. Wang, Q.; Wyman, D.A.; Xu, J.F.; Zhao, Z.H.; Jian, P.; Xiong, X.L.; Bao, Z.W.; Li, C.F.; Bai, Z.H. Petrogenesis of Cretaceous adakitic and shoshonitic igneous rocks in the Luzong area, Anhui Province (eastern China): Implications for geodynamics and $\mathrm{Cu}-\mathrm{Au}$ mineralization. Lithos 2006, 89, 424-446. [CrossRef]

91. Huang, J.; Zhao, D. High-resolution mantle tomography of China and surrounding regions. J. Geophys. Res. Solid Earth 2006, 111, 1-21. [CrossRef]

92. Zhu, R.X.; Fan, H.R.; Li, J.W.; Meng, Q.R.; Li, S.R.; Zeng, Q.D. Decratonic gold deposits. Sci. China Earth Sci. 2015, 58, 1523-1537, (In Chinese with English abstract). [CrossRef]

93. Li, S.Z.; Suo, Y.H.; Li, X.Y.; Zhou, J.; Santosh, M.; Wang, P. Mesozoic tectono-magmatic response in the east asian ocean-continent connection zone to subduction of the paleo-pacific plate. Earth-Sci. Rev. 2019, 192, 91-137. [CrossRef] 